\title{
AVALIAÇÃO DE DIFERENTES FONTES E TEORES DE PROTEÍNA DEGRADÁVEL NO RÚMEN SOBRE O DESEMPENHO E PARÂMETROS RUMINAIS E SANGÜINEOS DE VACAS HOLANDESAS EM FINAL DE LACTAÇÃO
}

\author{
HUGO IMAIZUMI
}

ZOOTECNISTA

Orientador: Prof. Dr. FLÁvIO AUGUSTO PORTELA SANTOS

Dissertação apresentada à Escola Superior de Agricultura "Luiz de Queiroz", Universidade de São Paulo, para a obtenção do título de Mestre em Agronomia, Ȧrea de Concentração: Ciência Animal e Pastagens.

PIRACICABA

Estado de São Paulo - Brasil

Maio de 2000 
Dados Internacionais de Catalogação na Publicação (CIP) DIVISÃO DE BIBLIOTECA E DOCUMENTAÇÃO - Campus "Luiz de Oueiroz"/USP

\author{
Imaizumi, Hugo \\ Avaliação de diferentes fontes e teores de proteina degradável no rúmen sobre $o$ \\ desempenho e parâmetros ruminais e sangüíneos de vacas holandesas em final de \\ lactação / Hugo Imaizumi, - - Piracicaba, 2000. \\ $69 \mathrm{p}$. \\ Dissertação (mestrado) - Escola Superior de Agricultura Luiz de Queiroz, 2000. \\ Bibliografia. \\ 1. Digestabilidade 2. Farelo de soja 3. Lactação 4. Proteína 5. Proteina microbiana \\ 6. Rúmen 7. Sincronização 8. Teor protéico 9 . Uréia 10. Vaca leiteira 1. Título
}

CDD 636.214 


\begin{abstract}
À minha mãe, Sadako e
Ao meu pai, Munekazu

Pela dedicação aos seus filhos e pelo incentivo, apoio, amizade e carinho que sempre demonstraram.
\end{abstract}

DEDICO 


\section{AGRADECIMENTOS}

À Escola Superior de Agricultura Luiz de Queiroz (USP) e em especial ao Departamento de Produção Animal - Setor de Ruminantes, pela oportunidade de realização deste curso.

Ao Prof. Dr. Flávio Augusto Portela Santos, pela orientação segura, pelos ensinamentos valiosos, pela amizade, confiança e exemplo de dedicação profissional.

À Coordenadoria de Aperfeiçoamento de Pessoal de Nível Superior (CAPES), pela concessão da bolsa de estudos durante o transcorrer do curso.

Ao Prof. Dr. José Manuel Corrêa de Simas, pelas sugestões, colaboração e orientação na execução deste trabalho, pela amizade e exemplo profissional.

Aos demais professores do Departamento de Produção Animal, pelos ensinamentos, cordialidade e pela amizade.

Aos amigos e colegas de curso Carla Maris de Bittar Nussio, Éberson de Castilho Barnabé, Sérgio de Oliveira Juchem e Miguel da Rocha Cavalcanti (Ribamar), pela amizade e pelo auxilio na condução do experimento de campo.

Ao funcionário do Laboratório de Bromatologia do Departamento de Produção Animal Carlos César Alves, pela amizade, paciência, ensinamentos e pela colaboração nas análises laboratoriais.

Aos demais funcionários e colegas do curso de pós-graduação, pela amizade, pela ajuda e pela agradável convivência.

À UNESP - Universidade Estadual Paulista "Júlio de Mesquita Filho" Câmpus de Botucatu, pela minha formação acadêmica.

Aos meus queridos pais Sadako e Munekazu, pela confiança e grande incentivo para execução deste trabalho.

Às pessoas que, direta ou indiretamente, contribuíram para a realização deste trabalho.

OBRIGADO. 


\section{ÍNDICE GERAL}

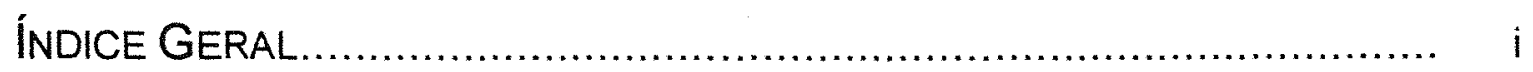

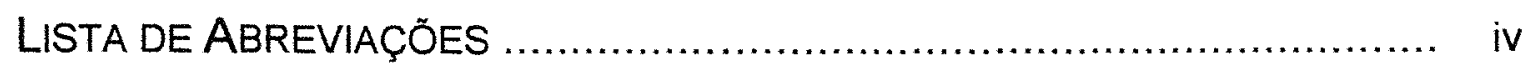

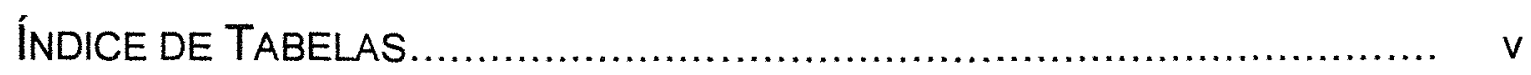

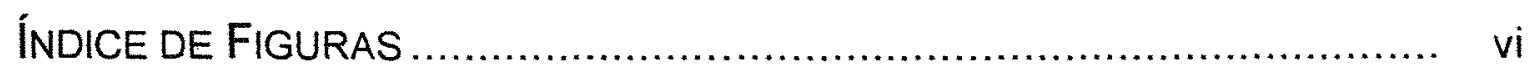

RESUMO

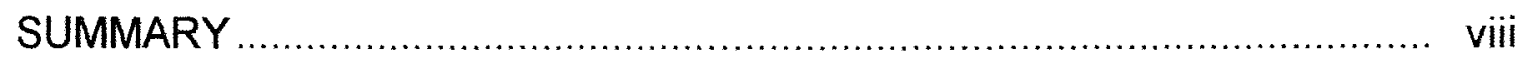

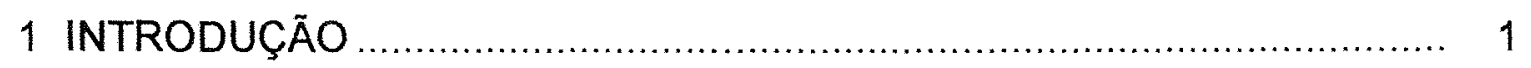

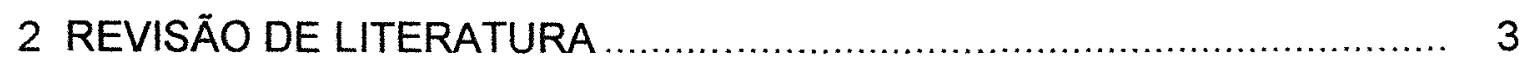

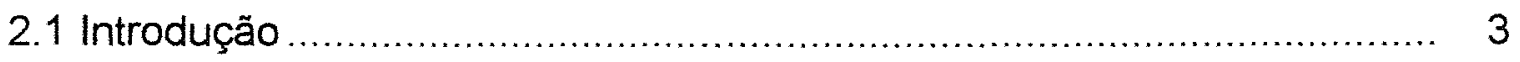

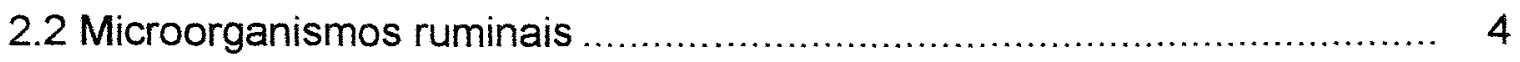

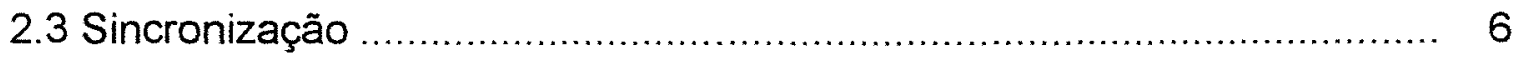

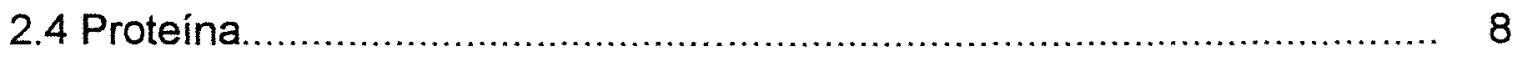

2.4.1 Histórico da nutrição protéica .............................................................. 9

2.4.1.1 Formulação por proteína bruta e por proteína não degradável no

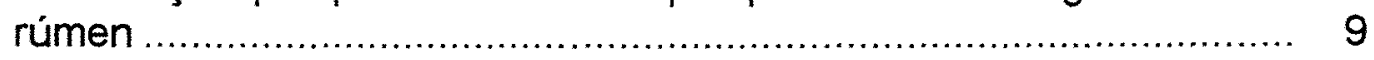

2.4.1.2 Formulação por aminoácidos ..................................................... 10

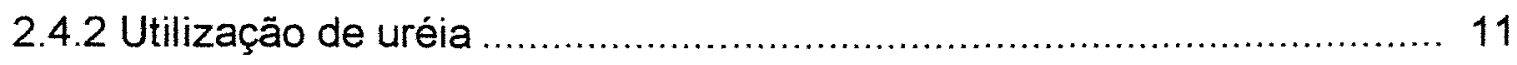

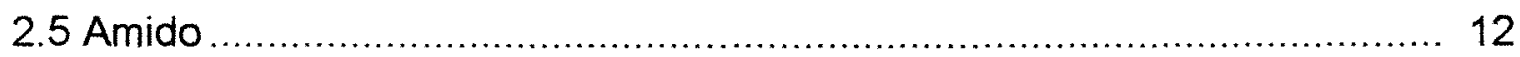

2.5.1 Processamento de grão de cereais ................................................ 12

2.5.2 Digestão ruminal do amido ........................................................... 13

2.5.3 Produtos da fermentaçăo ruminal ................................................... 14

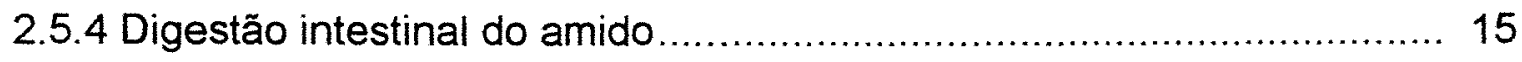

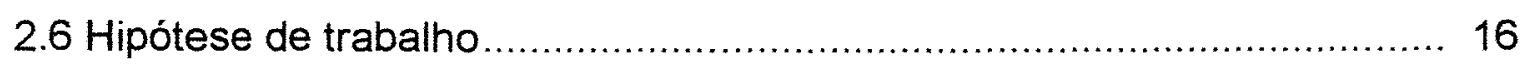

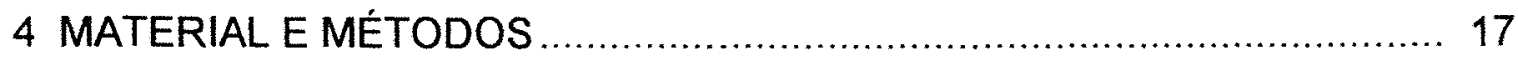

4.1 Animais e instalações experimentais ..................................................... 17

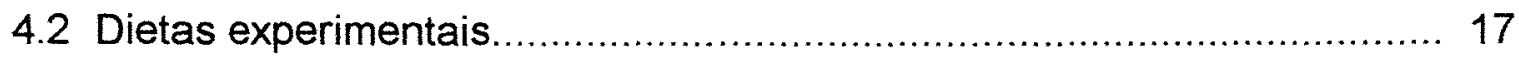

4.3 Periodo experimental .................................................................. 19

4.4 Marcador de digestibilidade ............................................................ 19

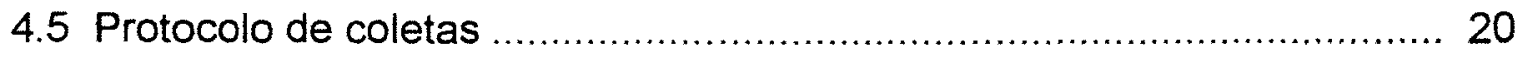


4.5.1 Pesagem e amostragem do alimento oferecido e recusado ............... 20

4.5.2 Pesagem e amostragem de leite................................................. 20

4.5.3 Coleta de amostras do duodeno .................................................. 21

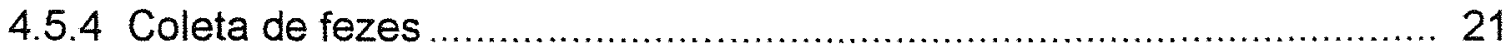

4.5 .5 Coleta de fluido ruminal .............................................................. 21

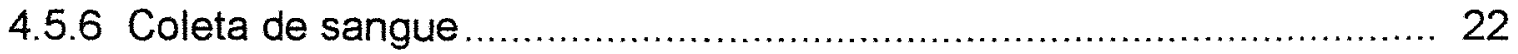

4.6 Preparo das amostras e análises laboratoriais .................................. 22

4.6.1 Análises químico-bromatológicas .............................................. 22

4.6.2 Análise de glucose e uréia plasmática......................................... 23

4.6.3 Análise de amônia e AGV no fluido ruminal.................................... 23

4.6.4 Análise da concentração de cromo ................................................ 24

4.6.5 Determinação do fluxo de proteína microbiana ................................ 24

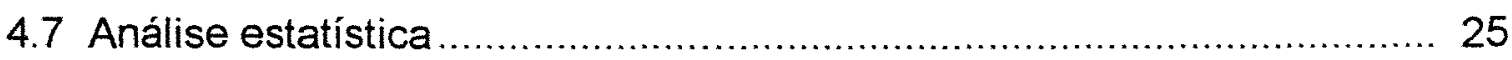

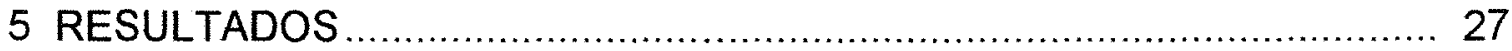

5.1 Consumo de matéria seca, matéria orgânica e nutrientes ................... 27

5.2 Produção e composição de leite ....................................................... 28

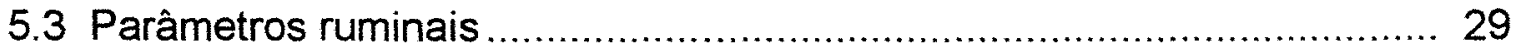

5.3.1 Concentração de nitrogênio amoniacal no rúmen .......................... 29

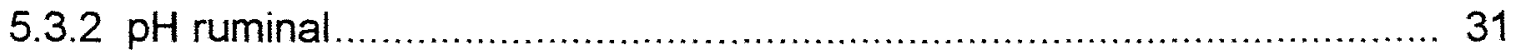

5.3 .3 Ácidos graxos voláteis ...................................................... 33

5.3.3.1 Ácidos graxos voláteis totais ............................................... 33

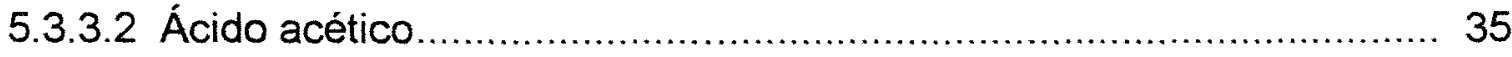

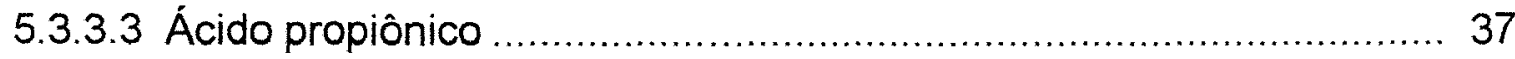

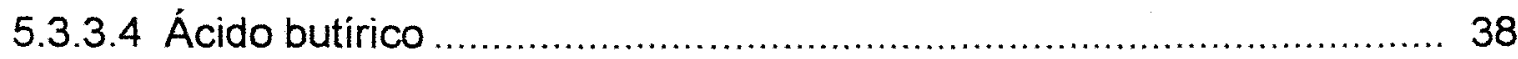

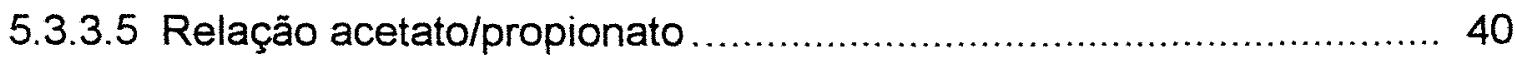

5.3.3.6 Ácido isobutírico, isovalérico e valérico ....................................... 42

5.4 Parâmetros sanguíneos ............................................................. 47

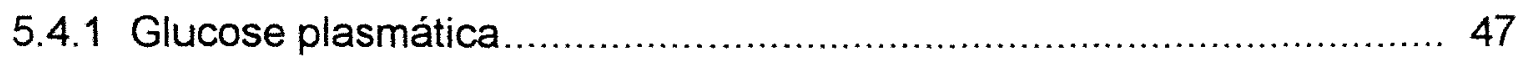

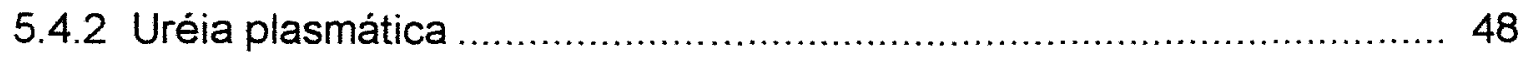

5.5 Digestibilidade de nutrientes..................................................... 50

5.6 Fluxo de proteina microbiana..................................................... 50 


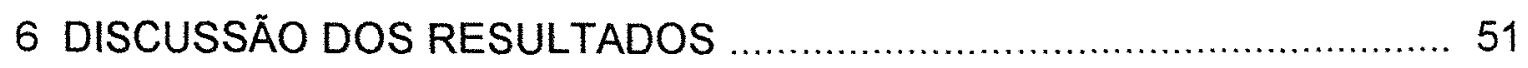

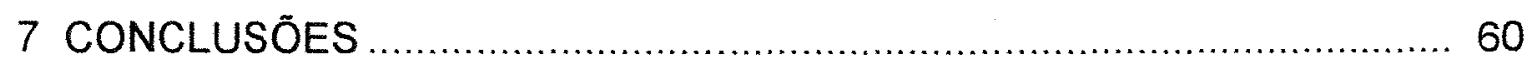

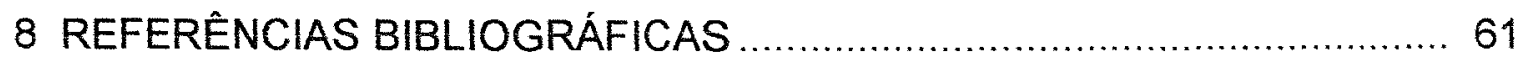




\title{
LISTA DE ABREVIAÇŌES
}

\author{
AA - Aminoácidos \\ AAE - aminoácidos essenciais \\ AGV - ácidos graxos voláteis \\ EE - extrato etéreo \\ ELLac - energia líquida de lactação \\ FDA - fibra em detergente ácido \\ FDN - fibra em detergente neutro \\ IMS - ingestão de matéria seca \\ Lis - Lisina \\ Met - Metionina \\ MM - matéria mineral \\ MO - matéria orgânica \\ MODR - matéria orgânica degradável no rúmen \\ MS - matéria seca \\ N - Nitrogênio \\ NNP - nitrogênio não protéico \\ PB - proteína bruta \\ PDR - proteína degradável no rúmen \\ PNDR - proteína não degradável no rúmen \\ PVD - proteína verdadeira degradável
}




\section{ÍNDICE DE TABELAS}

Tabela 1. Proporção dos ingredientes e composição média nutricional das dietas experimentais.

Tabela 2. Resumo esquemático da análise de variância para consumo de MS, eficiência alimentar, produção e composição do leite e digestibilidade dos nutrientes.

Tabela 3. Análise de variância para os parâmetros ruminais e sanguíneos

Tabela 4. Valores médios de consumo de matéria seca, matéria orgânica e nutrientes.

Tabela 5. Valores médios de consumo de MS, produção, composição, relação gordura/proteína e eficiência alimentar.

Tabela 6. Valores de quadrados mínimos da concentração de amônia

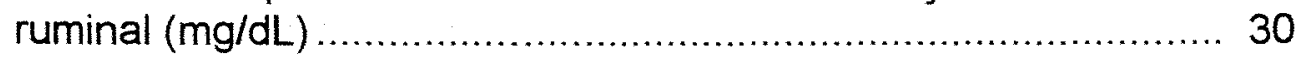

Tabela 7. Valores de quadrados mínimos do $\mathrm{pH}$ ruminal.

Tabela 8. Valores de quadrados mínimos da concentração total de AGV no rúmen $(\mathrm{mM})$...

Tabela 9. Valores de quadrados mínimos da porcentagem de acetato em relação ao total de $A G V$ no rúmen.

Tabela 10. Valores de quadrados minimos da porcentagem de propionato em relação ao total de AGV no rúmen.

Tabela 11. Valores de quadrados mínimos da porcentagem de butirato em relação ao total de $A G V$ no rúmen.

Tabela 12. Valores de quadrados mínimos da relação acetato:propionato produzidos no rúmen.

Tabela 13. Valores de quadrados mínimos da porcentagem de isobutirato em relação ao total de AGV no rúmen.

Tabela 14. Valores de quadrados mínimos da porcentagem de isovalerato em relação ao total de $A G V$ no rúmen.

Tabela 15. Valores de quadrados mínimos da porcentagem de valerato em relação ao total de $A G V$ no rúmen.

Tabela 16. Valores médios da concentração de glucose plasmática $(\mathrm{mg} / \mathrm{dL})$

Tabela 17. Valores médios da concentração de uréia plasmática $(\mathrm{mg} / \mathrm{dL})$... 


\section{AVALIAÇÃO DE DIFERENTES FONTES E TEORES DE PROTEÍNA DEGRADÁVEL NO RÜMEN SOBRE O DESEMPENHO E PARÂMETROS RUMINAIS E SANGÜINEOS DE VACAS HOLANDESAS EM FINAL DE LACTAÇÃO}

Autor: HUGO IMAIZUMI Orientador: Prof. Dr. FLÁVIO AUGUSTO PORTELA SANTOS

\section{RESUMO}

Foram utilizadas quatro vacas Holandesas alimentadas com silagem de milho e produzindo em torno de $12 \mathrm{~kg} /$ dia de leite, num delineamento em Quadrado Latino $4 \times 4$, com o objetivo de se avaliar o efeito de dietas com dois teores de $\mathrm{PB}$, provenientes de farelo de soja elou uréia, sobre o desempenho lactacional, digestibilidade de nutrientes e parâmetros ruminais e sanguíneos. As dietas continham milho floculado $(360 \mathrm{~g} / \mathrm{L})$ e o suplemento protéico oferecido foi farelo de soja elou uréia, variando-se o nível e fonte de proteína, de forma a obter quatro tratamentos distintos: (A) farelo de soja, apresentando 10,05\% de PB na dieta; (B) uréia, apresentando 10,05\% de PB na dieta; (C) farelo de soja e uréia, apresentando $13,70 \%$ de PB na dieta; e (D) farelo de soja, apresentando $13,70 \%$ de PB na dieta. Os tratamentos B e C caracterizavam-se por possuírem maiores teores de proteína degradável no rúmen. O consumo e eficiência alimentar, produção de leite, teores e produções de proteína e sólidos totais não foram afetados $(P>0,05)$. A utilização de uréia como fonte exclusiva de proteina levou a um aumento $(P<0,05)$ no teor de gordura sem, no entanto, alterar a produção de gordura $(P>0,05)$. Os parâmetros ruminais, como $\mathrm{pH}$, porcentagem de acetato, propionato, butirato, relação acetato:propionato e glucose plasmática não foram afetados $(P>0,05)$ pelos tratamentos. As dietas com maiores teores de PB levaram a um maior $(P<0,05)$ acúmulo de $A G V$ e a maiores $(P<0,05)$ concentrações de amônia ruminal e de uréia plasmática. 
EVALUATION OF DIFFERENT RUMINAL DEGRADED PROTEIN SOURCES AND

LEVELS ON PERFORMANCE, RUMEN FERMENTATION AND BLOOD PARAMETERS OF LATE LACTATION HOLSTEIN COWS

Author: HUGO IMAIZUMI

Adviser: Prof. Dr. FLÁVIO AUGUSTO PORTELA SANTOS

\section{SUMMARY}

Four lactating Holstein cows were used in a $4 \times 4$ Latin Square design to evaluate the effects of levels and sources on lactation performance, nutrient digestibilities, rumen fermentation and blood parameters. Cows were fed a $60 \%$ corn silage diet and a corn grain in the concentrate was fed at $360 \mathrm{~g} / \mathrm{L}$, urea (U) and soybeam meal (SBM) were used as treatment variables. Treatments were: (A) $10,05 \%$ CP diet - SBM; (B) $10,05 \%$ CP diet - U; (C) $13,70 \%$ CP diet SBM+U; (D) $13,70 \%$ CP diet - SBM. Dry matter instake, feed efficiency, milk production, milk protein percentage and production were not affected $(P>0,05)$ by treatments. Milk fat content was increased $(P>0,05)$ with de $10,05 \% \mathrm{CP}-\mathrm{U}$ diet (treatment $\mathrm{B}$ ). Ruminal's $\mathrm{pH}$, acetate, propionate and butirate concentrations and acetate:propionate ratio were not affected $(P>0,05)$ by treatments, however ruminal ammonia, total VFA and plasma urea nitrogen concentrations were increased $(P<0,05)$ with high $C P$ treatments. There was no treatments effect $(P>0,05)$ on plasma glucose concentrations. 


\section{INTRODUÇÃO}

Nos últimos 30 anos, estudos vêm sendo conduzidos quanto ao uso de diferentes fontes protéicas para vacas leiteiras, com o objetivo de maximizar a eficiência de utilização da proteina da dieta, através de melhor desempenho animal e menores perdas de nitrogênio $(\mathrm{N})$ para o ambiente.

A participação significativa dos suplementos protéicos no custo final das dietas para vacas em lactação e a capacidade dos ruminantes em utilizar fontes de nitrogênio não protéico (NNP), têm justificado o interesse pela utilização de uréia em substituição parcial ou total à fontes de proteina verdadeira.

A amônia é utilizada como fonte preferencial de $\mathrm{N}$ por bactérias fermentadoras de fibra (HUNGATE, 1966) e também é requerido por microorganismos que fermentam amido, açúcares e subprodutos secundários para a síntese protéica (COTTA \& RUSSEL, 1982). Esta amônia pode ser proveniente de proteína verdadeira de alimentos através da deaminação de aminoácidos (AA) por microorganismos ou pode vir diretamente de fontes de NNP.

Trabalhos "in vitro" conduzidos na década de 70 (SATTER \& SLYTER, 1974) sugeriram que 2 a $5 \mathrm{mg} / \mathrm{dl}$ de $\mathrm{N}$-amoniacal no fluido ruminal seriam suficientes para maximizar a síntese de proteina microbiana. Entretanto, HOOVER \& STOKES (1991) mostraram que niveis de proteina degradável no rúmen (PDR) superiores a $13 \%$ da matéria seca (MS) da dieta são necessários para maximizar o crescimento microbiano. Estes niveis de PDR, resultam 
invariavelmente em niveis de $\mathrm{N}$-amoniacal muito acima do proposto por SATTER \& SLYTER (1974).

A publicação do NRC (1985) e posteriormente o NRC (1989) de gado de leite, estimularam de forma expressiva o interesse por fontes suplementares ricas em proteina de baixa degradabilidade ruminal. $O$ conceito geralmente difundido foi 0 de que dietas contendo farelo de soja como o principal suplemento protéico seriam deficientes em proteína não degradável no rúmen (PNDR), limitando assim o desempenho de vacas leiteiras de alta produção. Entretanto, SANTOS et al. (1998) sumarizaram 127 comparações a partir de 88 estudos com vacas de alta produção, publicados entre 1985 a 1997, onde em apenas $17 \%$ dos casos, a substituição de farelo de soja por fontes ricas em PNDR resultou em aumento na produção de leite. Por outro lado, a mesma revisão mostrou que em 23 comparações onde a uréia substituiu parcial ou totalmente fontes de proteína verdadeira da dieta, a produção de leite não foi afetada em 17 e diminuiu em apenas 4 comparações. Já o teor de proteína do leite não foi afetado em 18 comparações e aumentou em 5 . A produção média de leite foi de $34,7 \mathrm{~kg} /$ dia para as dietas sem uréia contra $34,3 \mathrm{~kg} /$ dia para as dietas contendo uréia, demonstrando que para esse nível de produção, a inclusão de fontes de NNP não prejudica o desempenho lactacional.

$O$ presente experimento teve como objetivos avaliar a influência de diferentes teores e fontes de PDR sobre:

$\checkmark$ a ingestão de MS;

$\checkmark$ produção e composição do leite;

$\checkmark \mathrm{pH}$, concentração de ácidos graxos voláteis (AGV) e de $\mathrm{N}$-amoniacal no fluido ruminal;

$\checkmark$ digestibilidade dos nutrientes no rúmen, pós rúmen e no trato digestivo total;

$\checkmark$ concentração plasmática de uréia e glicose. 


\section{REVISÃO DE LITERATURA}

\subsection{Introdução}

Segundo o NRC (1985), uma porção da proteína ingerida pelo animal pode chegar ao omaso sem sofrer ação dos microorganismos ruminais, a qual é definida como proteína não degradável no rúmen (PNDR). A fração que sofre hidrólise ruminal, chamada de proteína degradável no rúmen (PDR), tem suas ligações peptídicas quebradas, formando peptídeos e aminoácidos (AA). Estes últimos podem ainda sofrer deaminação, ao final do qual são liberados amônia $\left(\mathrm{NH}_{3}\right)$ e alfa-cetoácidos. É importante ressaltar que inúmeras variáveis contribuem para a extensão de degradação da proteína no rúmen. A princípio, o que determinará essa extensão de degradação é o tipo de processamento do alimento e o tempo de retenção dele no rúmen. Desta forma, segundo o sistema de Cornell (CNCPS), o alimento possui sua porção nitrogenada dividida em três frações, a saber:

- fração A - Nitrogênio não protéico (NNP) e proteína solúvel;

- fração B - Proteina cuja degradabilidade é dependente da taxa de degradação e de passagem no rúmen;

- fração C - Proteína indisponível para o animal. 
Logo, pode-se concluir que a PNDR é composta por parte de fração B que atinge o omaso sem sofrer modificações pelos microorganismos ruminais e pela fração $\mathrm{C}$.

ARMENTANO et al. (1993) sugerem dividir a exigência de PDR em exigência de amônia e em exigência de proteína verdadeira degradável (PVD). Somente a PVD, proveniente de alimentos ou de origem endógena, pode proporcionar AA e peptídeos que permitem aumentar 0 crescimento microbiano. A PVD também é importante para a produção de AGV de cadeia ramificada (RUSSEL \& SNIFFEN, 1984), podendo ainda ser convertida em amônia, porém a uma taxa mais sincronizada com a energia disponível no rúmen, quando comparado com fontes de NNP tradicionais, como a uréia.

\subsection{Microorganismos ruminais}

Segundo OWENS \& ZINN (1988), os microorganismos ruminais geralmente contém entre 20 e $60 \%$ de sua MS na forma de $\mathrm{PB}$, sendo que as bactérias possuem uma média de $50 \%( \pm 5 \%)$ de PB na MS e os protozoários ao redor de $40 \%( \pm 20 \%)$. Para qualquer um deles, a fonte de $\mathrm{N}$ para a síntese protéica pode ser oriunda da proteína da dieta ou de NNP (dietético ou proveniente da reciclagem).

A amônia é utilizada como fonte preferencial de $\mathrm{N}$ para bactérias fermentadoras de fibra (HUNGATE, 1966). As que fermentam amido, açúcares e subprodutos secundários de fermentação para a síntese protéica também requerem amônia, porém têm suas sínteses aumentadas quando há disponibilidade de peptideos e AA (COTTA \& RUSSEL, 1982). Esta amônia pode ser proveniente de proteina verdadeira de alimentos através de deaminação de AA por microorganismos ou pode ser oriunda diretamente de NNP. 
No rúmen as bactérias requerem fontes de $\mathrm{N}$, energia, minerais, vitaminas e outros nutrientes para crescer. Contudo, $\mathrm{N}$ e energia são requeridos em quantidades maiores e exercem maior influência no crescimento bacteriano. Quando a proteína é degradada mais rapidamente do que é disponibilizada a fonte de energia, ocorre um desacoplamento da fermentação, aumentando a concentração de amônia ruminal, que é absorvida pela parede do rúmen e é convertida em uréia no fígado (NORLAN, 1975). Essa uréia pode ser reciclada via saliva ou parede do rúmen, mas a maior proporção é excretada na urina. NORLAN (1975) notificou em seus estudos que mais de $25 \%$ da proteína de origem alimentar é perdida na forma de amônia ruminal.

Contrariamente, quando grande quantidade de energia é degradada, ultrapassando a velocidade de degradação da proteína, o crescimento microbiano e a eficiência digestiva decrescem. Isto é caracterizado pela fermentação incompleta, onde os microorganismos, deficientes em $\mathrm{N}$, desviam ATP para o acúmulo de carboidrato e não para a síntese de proteína microbiana (NOCEK \& RUSSEL, 1988).

SATTER \& SLYTER (1974) sugeriram que a quantidade de $\mathrm{N}$ amoniacal no rúmen requerida para o máximo crescimento das bactérias ruminais seria de 2 a $5 \mathrm{mg} / \mathrm{dL}$. Contudo, o NRC (1985) sugere que, na realidade, o requerimento de amônia está relacionado à disponibilidade do substrato, à taxa de fermentação, à massa microbiana e ao nível de produção do animal. Dessa forma, como uma vaca de leite invariavelmente recebe uma dieta rica em matéria orgânica degradável no rúmen (MODR), a concentração ruminal de amônia dificilmente pode ser mantida em niveis tão baixos conforme aqueles propostos por SATTER \& SLYTER (1974), sem comprometer o desempenho animal.

CAMERON et al. (1991) observaram que a síntese de proteina microbiana e o crescimento microbiano depende de uma adequada quantidade de energia e N para a sintese e assimilação de aminoácidos. Uma sincronizada 
degradação ruminal e utilização de proteína e carboidratos da dieta é necessária para um ótimo crescimento microbiano e síntese protéica (RUSSEL \& HESPELL, 1981).

A energia é o fator mais limitante para o crescimento microbiano e para a síntese protéica no rúmen de vacas leiteiras (CAMERON et al., 1991). Contudo, fontes de $\mathrm{N}$ (amônia, AA e peptídeos) também podem limitar 0 crescimento microbiano e a síntese de proteína microbiana, principalmente quando dietas contendo uma alta concentração de PNRD são fornecidas (NOCEK \& RUSSEL, 1988).

\subsection{Sincronização}

A eficiência da produção animal é frequentemente limitada pela utilização de energia, e não pelo fornecimento de proteina, embora este último possa alterar o consumo de alimento e, desta forma, alterar a eficiência de produção (OWENS \& ZINN, 1988).

O fornecimento excessivo de proteína verdadeira para vacas de leite pode levar ao agravamento da contaminação ambiental (TAMMINGA, 1992) e à queda no desempenho reprodutivo (FERGUSON \& CHALUPA, 1989). No entanto, o consumo em excesso não representa, necessariamente, um desperdício, podendo ser utilizada como uma fonte de energia. Já o NNP, em contraste, pode causar um efeito negativo caso seja fornecido em excesso e leve a uma diminuição de consumo ou a um aumento de perda de energia pelo animal (NRC, 1989).

Os danos causados pela perda excessiva de $\mathrm{N}$ podem ser reduzidos através do aumento da captura do $\mathrm{N}$ degradado no rúmen pelos microorganismos ruminais (ARIELI et al., 1996). O crescimento microbiano e a sintese protéica pode ser estimulada por uma fermentação ruminal saudável 
(SNIFFEN \& ROBINSON, 1987) e pela diminuição da extensão dos distúrbios causados ao ambiente ruminal pelo manejo alimentar incorreto (ROBINSON, 1989). Uma das formas possíveis de se conseguir tal objetivo é através da sincronização da degradação de proteina e da matéria orgânica $(\mathrm{MO})$ no rúmen (DePETERS \& CANT, 1992; RUSSEL \& HESPELL, 1981).

A técnica de sincronização da degradação ruminal de proteína e amido propõe incrementar a produção de proteína microbiana no rúmen e a eficiência de utilização de energia, uma vez que as bactérias ruminais necessitam destes dois elementos disponiveis simultaneamente, segundo HERRERA-SALDANA \& HUBER (1989). Esses mesmos autores mostraram que a sincronização entre proteína e energia degradável foi benéfica em termos de crescimento das células microbianas, digestibilidade ruminal, eficiência na utilização de proteina e energia e na produção de leite. Portanto, seria interessante estudar quais as melhores combinações entre fontes de carboidrato e proteína degradáveis no rúmen.

HOOVER \& STOCKES (1991) compilaram informações de vários estudos em curvas de estimativa com o objetivo de quantificar os requerimentos e a degradabilidade de carboidratos em relação ao nivel de degradabilidade da proteína e sugeriram que o sincronismo foi importante na eficiência produtiva de ruminantes.

RUSSEL et al. (1983) concluíram que a disponibilidade de carboidrato reduziu o acúmulo de amônia no rúmen quando avaliaram o efeito da limitação de carboidrato na degradação e utilização da caseína pelas bactérias ruminais.

Em alguns trabalhos publicados, foram observados efeitos positivos quando se procurou aliar a alta degradabilidade ruminal de fontes de amido e de proteína nas dietas de vacas leiteiras. Nestes estudos, os efeitos positivos foram uma maior produção de leite (HERRERA-SALDANA \& HUBER, 1989), estimulos à produção de proteína microbiana no rúmen (HERRERA-SALDANA 
et al., 1990) e maior eficiência de utilização do $\mathrm{N}$ para a síntese microbiana (MOORE et al., 1992).

A incapacidade das vacas recém paridas de ingerirem a quantidade de energia requerida, aliada ao fornecimento de dietas ricas em proteína de alta degradabilidade ruminal, pode aumentar o acúmulo de amônia ruminal e levar a altos teores de uréia no sangue e no leite, porém com baixas concentrações de proteína no leite $(<3,2 \%)$, conforme relatado pelo NRC (1989). Tal fato ocorre devido à baixa produção de proteina microbiana causada pela falta de energia degradável no rúmen. Ainda segundo essa mesma fonte, vacas consumindo uma quantidade de energia adequada mas recebendo excesso de PDR poderão ter niveis elevados de amônia no rúmen e altos níveis de uréia no sangue e no leite, porém com concentrações normais de proteína no leite $(\geq$ $3,2 \%)$.

\subsection{Proteína}

Dentre as fontes protéicas existentes no Brasil, o farelo de soja é aquele que vem sendo utilizado mais comumente na formulação das dietas para bovinos leiteiros, quase sempre sendo incluído nas rações, independentemente do nivel de produção e/ou do estágio de lactação.

Segundo SCHWAB et al. (1976), tal ingrediente possui um teor de lisina (Lis) adequado, sendo, no entanto, deficiente em metionina (Met). Os dados publicados pelo NRC (1989) indicam um teor médio de $49,9 \%$ de PB, $84 \%$ de NDT e 1,94 Mcal/kg de energia líquida de lactação ( $\mathrm{LL}_{\mathrm{lac}}$ ), sendo que a PNDR representa $35 \%( \pm 12)$ da PB. 


\subsubsection{Histórico da nutrição protéica}

A partir das publicações do NRC (1985 e 1989) de gado de leite, houve um expressivo interesse pela utilização de fontes protéicas ricas em PNDR, pois acreditava-se que dietas para vacas em lactação contendo o farelo de soja como o principal suplemento protéico seriam deficientes em PNDR, limitando assim o desempenho lactacional.

\subsubsection{Formulação por proteína bruta e por proteína não degradável no rúmen}

No passado, uma formulação tradicional de dieta para vacas leiteiras era feita simplesmente se respeitando o teor mínimo exigido de PB na matéria seca e nos últimos 10-15 anos, passou-se a utilizar conceitos de degradabilidade ruminal da proteína na formulação das rações (SCHWAB, 1996; SLOAN et al., 1999). O objetivo era, em primeiro lugar, proporcionar uma quantidade adequada de proteína degradável para se otimizar as funçōes ruminais e maximizar a síntese protéica. Em segundo lugar, visava-se fornecer proteína digestivel resistente à degradação ruminal, proporcionando um complemento à proteína microbiana e, dessa forma, atender às exigências de proteína metabolizável e de AA (SCHWAB, 1996; RULQUIN \& VERITÉ, 1993).

Até recentemente, acreditava-se que o teor de PNDR na dieta das vacas em lactação deveria ser aumentada conforme a produção de leite fosse aumentando, já que o potencial de produção cresce mais rapidamente do que a ingestão de matéria seca (IMS) (SLOAN et al., 1999). Entretanto, hoje é sabido que tais pressuposições estavam equivocadas.

SANTOS et al. (1998) sumarizaram 127 comparações a partir de 88 estudos com vacas de alta produção, publicados entre 1985 a 1997. Em 
apenas $17 \%$ dos casos, a substituição de farelo de soja por fontes ricas em proteína de baixa degradabilidade ruminal resultou em aumento na produção de leite. Os mesmos autores observaram que na maioria dos ensaios de metabolismo com vacas canuladas no rúmen e duodeno, o aumento no teor de PNDR na dieta reduziu a síntese de proteína microbiana e aumentou o fluxo de proteína de origem dietária para o intestino sem, no entanto, alterar o fluxo de proteína total.

\subsubsection{Formulação por aminoácidos}

Uma das prováveis causas da ausência de resposta em produção de leite à suplementação com PNDR pode ser o fato de que a maioria destas fontes protéicas têm o perfil de AA inadequado. As fontes de PNDR diferem consideravelmente entre si no tocante à digestibilidade de nutrientes e à composição de AA (SCHWAB, 1996). Quando a exigência de AA limitantes não é atendida, o animal não responde em produção, fazendo com que o animal deamine e excrete o excesso de $A A$, com um gasto de energia que poderia ser melhor utilizado para a produção de leite (SLOAN et al., 1999). Segundo SWENSON \& REECE (1996), são gastos 4 ATPs para cada mol de uréia produzida no organismo animal.

O teor e produção de proteína do leite são afetados principalmente pela quantidade e pelo perfil de $A A$ que chegam ao duodeno. Dos $A A$ importantes para a síntese de proteína pela glândula mamária, a Lis e a Met se destacam pelo fato de serem os AA mais limitantes para tal finalidade (FRASER et al., 1991; SCHWAB et al., 1992) e a sua maximização é possível de ser atingida caso a porcentagem destes dois AA no bolo alimentar do duodeno esteja em torno de 15 e $5 \%$ dos aminoácidos essenciais (AAE), respectivamente para a Lis e Met (SCHWAB 1994), ou como mais 
recentemente preconizado por SLOAN et al. (1999), 6,82 e 2,19\% de Lis e Met, respectivamente, na proteina metabolizável que chega ao duodeno. Das fontes protéicas comerciais, apenas a farinha de peixe possui Lis e Met em quantidades e proporções adequadas, o que explica o fato dela ser a fonte protéica rica em PNDR que tem apresentado os melhores resultados quando incluído na dieta de vacas de alta produção com o objetivo de se aumentar o suprimento de PNDR (SANTOS et al.,1998).

\subsubsection{Utilização de uréia}

Em virtude da equivocada pressuposição de que vacas de alta produção sempre responderiam à suplementação com fontes ricas em PNDR, a utilização de uréia na formulação de dietas de vacas de alta produção tem sido pouco estudada (SANTOS et al., 1998).

De acordo com o NRC (1989), quando há um fornecimento de NNP como fonte exclusiva de $\mathrm{N}$, há síntese de proteína microbiana suficiente para que bezerros já com o rúmen funcional ganhem em torno de $65 \%$ do peso que ganhariam caso fossem alimentados com dietas formuladas adequadamente. Esta mesma publicação relata que vacas leiteiras alimentadas com dietas livre de proteína foram capazes de produzir $4.000 \mathrm{~kg}$ de leite durante uma lactação. No entanto, essa produção poderia ser aumentada em 1.000 e $1.500 \mathrm{~kg}$ de leite, caso fosse suplementada proteína de forma a atingir 20 e $40 \%$ do $\mathrm{N}$ requerido, respectivamente.

A revisão de literatura publicada por SANTOS et al. (1998) mostrou que em 23 comparações onde a uréia substituiu parcial ou totalmente fontes de proteina verdadeira da dieta, a produção de leite não foi afetada em 17 , aumentou em duas e diminuiu em apenas 4 comparações. O teor de proteína do leite não foi afetado em 18 comparações e aumentou em 5 . A produção 
média de leite foi de $34,7 \mathrm{~kg} /$ dia para as dietas sem uréia contra $34,3 \mathrm{~kg} / \mathrm{dia}$ para as dietas contendo uréia, demonstrando que para esse nível de produção, a inclusão de fontes de NNP não prejudica o desempenho lactacional.

\subsection{Amido}

O amido representa 70 a $80 \%$ da MS da maioria dos cereais como milho, sorgo, cevada, trigo e aveia e é normalmente a fonte primária de energia em dietas de ruminantes com o objetivo de se obter alto desempenho (ROONEY \& PFLUGFELDER, 1986). Em torno de 25 a $35 \%$ da MS das dietas para vacas de leite de alta produção é representada por amido. Sendo assim, a utilização eficiente do amido é fundamental para se maximizar a produção de vacas de leite.

\subsubsection{Processamento de grão de cereais}

O milho e o sorgo são alimentos utilizados principalmente pela energia proveniente do amido, e diferentes formas de processamento podem ser aplicadas para maximizar a sua eficiência. Os métodos de processamento estão geralmente associados com a melhoria na eficiência da utilização dos grãos e podem ser divididos em processos físicos e químicos (NOCEK \& TAMMINGA, 1991).

O processamento físico usualmente consiste na quebra, moagem, trituração, ou peletização de grãos secos. Modificações físico-quimicas envolvem a aplicação de calor e água, que hidrata e incha as estruturas amorfas e cristalinas dos grãos de amido. Estas alterações na estrutura aumentam a digestão amilolítica por enzimas de microorganismos e pancreáticas. O grão inteiro com o pericarpo intacto é altamente resistente à 
digestão por ruminantes por não permitir adesão de bactérias (MCALLISTER et al. 1994; BAUACHEMIN et al., 1994). O processamento com umidade e vapor também quebra as matrizes e corpos protéicos que dificultam a digestão do amido, permitindo um maior acesso à digestão enzimática (NOCEK \& TAMMINGA, 1991). A reconstituição, que consiste no aumento de umidade até $30 \%$ e na armazenagem anaeróbia do grão por 2-3 semanas antes da moagem e utilização, também melhora a utilização do amido por ruminantes. A maioria dos métodos de processamento aumenta a digestibilidade de amido no rúmen, - que usualmente aumenta a digestibilidade de amido no intestino delgado (OWENS \& GOETSCH, 1986).

A floculação é uma forma de processamento do milho ou sorgo consiste da aplicação de vapor por 30 a 40 minutos sobre o grão, que absorve água e incha. Desse modo, tem-se início o processo de gelatinização do amido, aumentando sua digestibilidade. Então os grãos são passados através de rolos, ocorrendo o processo de floculação, onde a área superficial é aumentada significativamente e as matrizes protéicas que envolvem os grãos de amido são quebradas. O resultado final é o aumento da digestibilidade do amido (THEURER et al., 1995). Trabalhos conduzidos na Universidade do Arizona têm mostrado de forma consistente que quando a degradabilidade ruminal do amido é aumentada através da floculação do milho ou sorgo, a produção de leite $(5$ a $10 \%)$ e de proteína do leite $(12$ a $16 \%$ ) são incrementadas devido a uma maior disponibilidade de energia e proteína para a glândula mamaria (THEURER et al., 1993).

\subsubsection{Digestão ruminal do amido}

O rúmen mostra-se como o principal sítio de digestão do amido (THEURER, 1986) e, segundo THEURER (1992), os principais fatores que 
determinam a quantidade de energia extraída dos grãos de cereais são a taxa e o grau de digestão no rúmen.

Vários gêneros de bactérias ruminais são consideradas como amiloliticas, podendo-se citar como exemplos alguns deles, como Bacterioides, Butyrivibrio, Eubacterium, Lactobacillus, Ruminobacter, Selenomonas, Streptococcus, Succinomonas e Succinovibrio (KOTARSKI et al., 1992; VAN SOEST, 1994).

As enzimas atuantes das espécies amilolíticas age clivando aleatoriamente as moléculas de amido (YOKOYAMA \& JOHNSON, 1988). Após serem geradas maltose, maltotrioses e glucose a partir do amido e dextranas (BERGMAN, 1990), as bactérias sacarolíticas encarregam-se de fermentar tais substratos, produzindo piruvato (FAHEY \& BERGER, 1988). De cada mol de hexose degradada, são produzidos 2 mols de piruvato, 2 mols de trifosfato de adenosina (ATP) e 2 mols de dinucleotídeo de nicotinamida-adenina reduzida (NADH) (LEHNINGER, 1988).

\subsubsection{Produtos da fermentação ruminal}

O piruvato produzido pode ser oxidado a acetato, propionato, butirato ou lactato (BERGMAN, 1990) e a proporção molar produzida é dependente de fatores como tipo de carboidrato fermentado no rúmen, tempo e extensão de degradação, espécies de bactérias existentes e ambiente ruminal (VAN SOEST, 1994).

Portanto, neste processo todo de fermentação ruminal, os polimeros de açúcar produzidos a partir da atividade enzimática das bactérias amilolíticas servem como substratos para outras espécies produzirem AGV e gás carbônico $\left(\mathrm{CO}_{2}\right)$ (HUNTINGTON, 1994). 
Os AGV produzidos são quase que totalmente $(85$ a $100 \%$, segundo REYNOLDS \& HUNTINGTON, 1988) absorvidos pelo epitélio ruminal de forma passiva e, descontando-se aquela porção que é utilizada pelo próprio tecido epitelial, chegam ao figado, através do sistema porta. Segundo BERGMAN (1990), o fator que determina o local de metabolismo dos AGV é a presença e alta atividade das enzimas CoA sintetase nos diferentes tecidos. Dessa forma, cerca de $90 \%$ do butirato produzido no rúmen é metabolizado pelo próprio epitélio ruminal, uma vez que ele possui uma alta atividade da enzima ButirilCoA sintetase. A enzima propionil-CoA sintetase tem baixa atividade no epitélio ruminal, porém alta no fígado. Tal fato determina uma metabolização de cerca de 3 a 15\% no epitélio ruminal e uma maior proporção de metabolismo no fígado, que utiliza tal substrato como precursor gluconeogênico. Já a enzima acetil-CoA sintetase possui uma baixa atividade tanto no fígado quanto no epitélio ruminal, porém alta atividade nos tecidos musculares e adiposos (tecidos periféricos), fato este que determina uma alta metabolização do acetato nestes locais (BERGMAN, 1990).

\subsubsection{Digestão intestinal do amido}

No lúmen do intestino delgado, o amido que escapa da degradação ruminal sofre uma ação de enzimas digestivas capazes de clivar as ligações glucosídicas presentes na amilose e amilopectina, produzindo uma mistura de glucose e oligossacarídeos de duas (maltose), três (maltotriose) e sete (dextrina) unidades de glucose (HARMON, 1992). No entanto, para que haja absorção por parte dos enterócitos, é necessário que os oligossacarídeos sejam hidrolisados (por meio de oligossacaridases e dextrinases) de forma a produzir glucose, que por sua vez são passíveis de serem transportadas ativamente para o interior das células (GRAY, 1992). 
O amido que escapa da degradação no rúmen e no intestino delgado atinge o ceco e o cólon, onde poderá sofrer uma fermentação por parte das bactérias que ali colonizam, produzindo AGV, que podem ser absorvidos e atingir o sistema porta-hepático (ARMENTANO, 1992).

\subsection{Hipótese de trabalho}

De acordo com a revisão de literatura apresentada, a utilização de uréia como fonte de $\mathrm{N}$ para vacas de leite de média/alta produção vem sendo pouco estudada, haja visto que vinha sendo enfatizado o uso de PNDR nas formulações das dietas. Contudo, os resultados obtidos pelos trabalhos conduzidos nem sempre foram satisfatórios em termos de produção, composição do leite e fluxos de proteina e de AA essenciais para o intestino, uma vez que a maioria destas fontes protéicas ricas em PNDR utilizadas eram pobres elou desbalanceadas no teor de Lis e Met em relação ao total de AAE e, ainda, limitavam o fluxo de $\mathrm{N}$ microbiano para o intestino delgado. De acordo com os conceitos atuais de nutrição protéica, a proteína microbiana sintetizada no rúmen é considerada como sendo de excelente qualidade e a sua produção deve ser estimulada ao máximo, uma vez que o perfil de AAE é muito bem balanceada.

Assim, faz-se necessária a realização de pesquisas de metabolismo e produção que identifiquem uma combinação mais adequada de fontes de PDR e de carboidrato de alta degradabilidade ruminal que estimulem a máxima produção de proteína microbiana no rúmen e, ainda, que verifiquem os efeitos da substituição parcial ou total de farelo de soja por uréia dentro de um mesmo nivel de PB. 


\section{MATERIAL E MÉTODOS}

\subsection{Animais e instalações experimentais}

O experimento foi conduzido entre $18 / 03$ e 23/06 de 1998 nas dependências do Laboratório de Nutrição de Ruminantes do Departamento de Produção Animal da Escola Superior de Agricultura "Luiz de Queiroz" - USP.

Foram utilizadas quatro vacas Holandesas, multiparas, com 180 dias de lactação em média, produzindo aproximadamente $12 \mathrm{~kg}$ de leite/dia, com peso médio de aproximadamente $600 \mathrm{~kg}$ e providas de fístulas ruminais e duodenais. A fístula duodenal do tipo T localizava-se a $10 \mathrm{~cm}$ do piloro.

Os animais foram alojados em um galpão coberto equipado com ventiladores e mantidos em baias individuais do tipo "tie stall" $(2,5 \times 1,1 \mathrm{~m})$. Os comedouros eram individuais e cada bebedouro era compartilhado por duas vacas.

\subsection{Dietas experimentais}

As dietas foram formuladas para conter $60 \%$ de volumoso e $40 \%$ de concentrado, na MS, sendo usado exclusivamente silagem de milho como volumoso e o concentrado continha basicamente milho floculado (densidade de $360 \mathrm{~g} / \mathrm{L}$ ), uma fonte ou uma combinação de fontes de proteína, minerais e vitaminas. Os tratamentos foram: 
A) dieta contendo $10,05 \%$ de PB com farelo de soja como fonte protéica;

B) dieta contendo $10,05 \%$ de PB com uréia como fonte protéica;

C) dieta contendo $13,70 \%$ de PB com farelo de soja e uréia como fontes protéicas;

D) dieta contendo $13,70 \%$ de PB com farelo de soja como fonte protéica.

A proporção dos ingredientes e a composição média nutricional das quatro dietas experimentais estão apresentadas na Tabela 1.

Tabela 1. Proporção dos ingredientes e composição média nutricional das dietas experimentais.

\begin{tabular}{|c|c|c|c|c|}
\hline & \multicolumn{4}{|c|}{ TRATAMENTOS } \\
\hline & \multicolumn{2}{|c|}{$10,05 \%$ PB } & \multicolumn{2}{|c|}{$13,70 \%$ PB } \\
\hline & $\mathbf{A}$ & B & C & D \\
\hline Ingredientes & \multicolumn{4}{|c|}{ (\% da MS total) } \\
\hline $\begin{array}{l}\text { Silagem de milho } \\
\text { Farelo de soja } \\
\text { Milho floculado } \\
\text { Minerais } \\
\text { Sulfato de amônio } \\
\text { Uréia }\end{array}$ & $\begin{array}{r}59,85 \\
5,53 \\
32,23 \\
2,17 \\
0,22 \\
0,00\end{array}$ & $\begin{array}{r}59,87 \\
0,00 \\
36,87 \\
2,17 \\
0,34 \\
0,75\end{array}$ & $\begin{array}{r}59,87 \\
5,54 \\
30,85 \\
2,17 \\
0,22 \\
1,34\end{array}$ & $\begin{array}{r}59,87 \\
14,89 \\
22,84 \\
2,17 \\
0,22 \\
0,00\end{array}$ \\
\hline \multicolumn{5}{|l|}{ Composição } \\
\hline $\begin{array}{l}\text { MS (\%) } \\
\text { Cinzas (\% da MS) } \\
\text { PB (\% da MS) } \\
\text { PDR * (\% da PB) } \\
\text { EL (Mcal/kg) } \\
\text { EE (\% da MS) } \\
\text { FDN (\% da MS) } \\
\text { FDN proveniente de volumoso (\% da MS) } \\
\text { FDA (\% da MS) } \\
\text { Amido (\% da MS) } \\
\text { Carboidratos não fibrosos (\% da MS) }\end{array}$ & $\begin{array}{r}37,83 \\
5,65 \\
10,05 \\
62,54 \\
1,54 \\
3,13 \\
41,52 \\
31,72 \\
22,05 \\
37,13 \\
41,53\end{array}$ & $\begin{array}{r}39,17 \\
5,62 \\
10,05 \\
69,87 \\
1,53 \\
3,22 \\
42,06 \\
31,73 \\
22,06 \\
38,90 \\
41,19\end{array}$ & $\begin{array}{r}37,36 \\
5,64 \\
13,70 \\
73,00 \\
1,51 \\
3,08 \\
41,14 \\
31,73 \\
21,91 \\
32,69 \\
38,00\end{array}$ & $\begin{array}{r}38,21 \\
6,02 \\
13,70 \\
63,92 \\
1,53 \\
2,92 \\
40,21 \\
21,73 \\
21,96 \\
34,85 \\
38,88\end{array}$ \\
\hline
\end{tabular}

* Calculado segundo o NRC (1989). 
A composição nutricional de cada uma das dietas foi calculada com base nos valores de tabela da composição nutricional dos ingredientes presentes em cada tratamento.

Para cada subperíodo o concentrado foi previamente misturado em misturador horizontal (marca Lucato, capacidade $500 \mathrm{~kg}$ ), adicionando-o à silagem de milho no momento do fornecimento da alimentação.

A dieta foi oferecida "ad libitum" às $6: 00 \mathrm{~h}$ e 18:00 $\mathrm{h}$, sendo permitido uma sobra de $10 \%$, com o intuito de não se limitar a ingestão de MS.

\subsection{Periodo experimental}

O período experimental consistiu de quatro subperíodos de 21 dias cada, sendo 17 dias utilizados na adaptação dos animais à dieta e 4 dias utilizados para coleta. Durante o período de adaptação as vacas foram soltas diariamente para exercicio em um piquete adjacente ao galpão por 1 hora e durante o período de coleta permaneciam nas baias individuais na integralidade do tempo.

\subsection{Marcador de digestibilidade}

Utilizou-se óxido de cromo como marcador externo para a determinação de fluxo de nutrientes e digestibilidade no rúmen e trato digestivo total. A dose utilizada foi de $0,4 \%$ da MS da dieta por dia, colocado diretamente no rúmen via cânula, duas vezes ao dia, durante os 10 últimos dias de cada subperíodo, isto é, do $11^{\circ}$ ao $21^{\circ} \mathrm{dia}$. 


\subsection{Protocolo de coletas}

\subsubsection{Pesagem e amostragem do alimento oferecido e recusado}

Os concentrados foram amostrados separadamente em cada subperiodo, formando amostras compostas por vaca e subperíodo. A silagem de milho foi amostrada por ocasião de seu fornecimento, formando uma amostra composta para cada subperiodo. O alimento recusado, que era retirado somente antes do fornecimento da alimentação vespertina foi composto por vaca e subperíodo. As amostras do alimento oferecido e recusado foram congeladas a $-10{ }^{\circ} \mathrm{C}$ para posterior análise químicobromatológica.

Durante os 4 dias de coleta de cada subperiodo, realizaram-se registros diários das quantidades oferecidas e das respectivas sobras por vaca. Sub-amostras do alimento oferecido e das sobras foram secas a $105^{\circ} \mathrm{C}$ para o cálculo da ingestão de MS dos animais.

\subsubsection{Pesagem e amostragem de leite}

As vacas foram ordenhadas duas vezes ao dia, às 6:00 h e às 18:00 h, realizando-se pesagem e amostragem do leite durante os 4 dias de coleta de cada subperiodo. As amostras foram compostas por dia e por cada vaca dentro do subperíodo, preservadas com 2-bromo-2-nitropropano-1-3-diol e armazenadas em geladeira até o término das coletas de cada subperíodo para posteriores determinações de proteína, gordura, lactose e sólidos totais pelo Laboratório de Análises de Leite do Departamento de Produção Animal da ESALQ-USP. 


\subsubsection{Coleta de amostras do duodeno}

Durante os quatro dias de coleta de cada subperíodo, amostras do bolo alimentar do duodeno, equivalente a $300 \mathrm{~mL}$, foram coletadas com intervalos de 4 horas, atrasando-se uma hora por dia, de modo que cada hora do dia fosse representada, perfazendo um total de aproximadamente 7,2 litros. As amostras foram agrupadas por vaca e subperíodo e armazenadas a $-10{ }^{\circ} \mathrm{C}$ para posterior análise químico-bromatológica.

Para a determinação da composição bacteriana, uma segunda amostragem do bolo alimentar do duodeno, equivalente a $500 \mathrm{~mL}$, foi realizada a cada 4 horas durante o terceiro dia de coleta, perfazendo um total de 3 litros. O material coletado foi batido em liquidificador por 20 segundos, coado em panos de fralda, armazenado em $a-10^{\circ} \mathrm{C}$ para posterior análise de purina.

\subsubsection{Coleta de fezes}

Amostras de aproximadamente $100 \mathrm{~g}$ de fezes foram obtidas do reto dos animais, com intervalos de 4 horas, durante os 4 dias de periodo de coleta, atrasando-se 1 hora por dia. As amostras de fezes foram compostas por vaca e por subperiodo, sendo após armazenadas $\mathrm{a}-10^{\circ} \mathrm{C}$.

\subsubsection{Coleta de fluido ruminal}

O fluido ruminal foi amostrado no segundo dia de coleta de cada subperíodo, no momento do fornecimento matinal da alimentação e após 4 , 8 , 12,16 e 20 horas. 
Antes da amostragem procurou-se homogeneizar o conteúdo com as mãos, após o qual foram tomadas 4 aliquotas de diferentes pontos para ser coado em pano de fralda.

$\mathrm{O} \mathrm{pH}$ foi imediatamente determinado utilizando-se um potenciômetro digital (Digimed modelo TE-902). Duas sub-amostras de $25 \mathrm{~mL}$ do fluido ruminal foram congeladas a $-10^{\circ} \mathrm{C}$ utilizando-se ácido clorídrico $6 \mathrm{~N}$ como conservante, para posterior análise de amônia ( $\mathrm{N}$-amoniacal) e ácidos graxos voláteis (AGV).

\subsubsection{Coleta de sangue}

No primeiro dia de coleta de cada subperiodo, coletou-se amostras de sangue através de punção na veia coccígea nos horários $0,2,4,6,12$ e 18 horas após o fornecimento matinal do trato. Utilizou-se tubos de vidro com vácuo, contendo fluoreto de sódio como antiglicolítico e oxalato de potássio como anticoagulante. Após as amostras de sangue serem centrifugadas a 4.000 × G por 15 minutos, as amostras de plasma foram acondicionadas em tubos "eppendorf" e congeladas a $-10^{\circ} \mathrm{C}$.

\subsection{Preparo das amostras e análises laboratoriais}

\subsubsection{Análises químico-bromatológicas}

As amostras de alimento oferecido, do recusado, do bolo alimentar duodenal e das fezes foram secas a $55^{\circ} \mathrm{C}$ durante $72 \mathrm{~h}$, moídas em moinho tipo "Willey" com peneira de $1 \mathrm{~mm}$ e analisadas para MS, MO, PB e extrato etéreo (EE) de acordo com o AOAC (1990), amido pelo método descrito por 
POORE et al. (1991), fibra em detergente neutro (FDN) e fibra em detergente ácido (FDA) de acordo com VAN SOEST et al. (1991).

\subsubsection{Análise de glucose e uréia plasmática}

A glucose plasmática foi lida em um autoanalisador YSI 2.700 Select (Biochemistry Analyser, Yellow Spring - $\mathrm{OH}$ ). A uréia plasmática foi analisada de acordo com o método colorimétrico descrito por CHANEY \& MARBACH (1962) e adaptado para ser usado em placas de microtítulo e lido em aparelho do tipo Elisa Reader BIO RAD (absorbância de 550 nanômetros).

\subsubsection{Análise de amônia e AGV no fluido ruminal}

As amostras de fluido ruminal foram descongeladas e centrifugadas a $11.000 \times \mathrm{G}$ a $4{ }^{\circ} \mathrm{C}$, durante 20 minutos. Do sobrenadante, foram tomadas 2 alíquotas.

Para compor a primeira alíquota, $2 \mathrm{~mL}$ do sobrenadante foram acondicionados em tubos "eppendorf" e recongelados $-10^{\circ} \mathrm{C}$ para posterior análise da concentração de amônia, de acordo com o método colorimétrico descrito por CHANEY \& MARBACH (1962) e adaptado para ser usado em placas de microtítulo e lido em aparelho do tipo Elisa Reader BIO RAD (absorbância de 550 nanômetros).

Outra aliquota de $800 \mu \mathrm{L}$ foi obtida do sobrenadante, após o qual foi adicionado $100 \mu \mathrm{L}$ de solução de padrão interno (ácido 2-etilbutírico) e $200 \mu \mathrm{L}$ de ácido metafosfórico a $25 \%$, para posterior análise de AGV, de acordo com PALMQUIST \& CONRAD (1971), utilizando frascos para leitura em cromatógrafo liquido-gasoso Hewlett-Packard 5890, Series II (Hewlett-Packard 
Company, Avondale, PA) e equipado com Integrador HP (Hewlett-Packard Company, Avondale, PA). Foi utilizado nitrogênio como gás de arraste e a temperatura do injetor, detector e coluna foram, respectivamente, 160, 190 e $115^{\circ} \mathrm{C}$.

\subsubsection{Análise da concentração de cromo}

As concentrações de cromo nas amostras do conteúdo duodenal e das fezes foram determinadas de acordo com o método de FENTON \& FENTON (1979), com leitura em espectrofotômetro de absorção atômica.

Entretanto, houve baixa recuperação de marcador e os valores de concentração de cromo encontrados não possibilitaram a avaliação da digestibilidade no rúmen, pós rúmen e trato digestivo total, impossibilitando o cálculo de fluxo de nutrientes para o duodeno.

Em vista dos problemas ocorridos com a recuperação do cromo, a lignina foi usada como marcador interno, mas novamente as digestibilidades não puderam ser calculadas, devido aos teores incoerentes de lignina obtidos.

A digestibilidade aparente (D) no trato total da MS e demais nutrientes da dieta foram calculados com a seguinte fórmula:

$$
D(\%)=100-\left(100 \times \frac{\% \text { do marcador na dieta }}{\% \text { do marcador nas fezes }} \times \frac{\% \text { do mutriente nas fezes }}{\% \text { do mutriente na dieta }}\right)
$$

\subsubsection{Determinação do fluxo de proteína microbiana}

As amostras de conteúdo duodenal foram descongeladas e centrifugadas em baixa rotação (2.000 X G por 15 minutos) com o intuito de se 
recuperar o sobrenadante. Este foi centrifugado em alta rotação (18.000 X G por 15 minutos). $O$ "pellet" formado, rico em bactérias, foi congelado a $-10^{\circ} \mathrm{C}$, para análise de purina pelo método de ZINN \& OWENS (1986).

\subsection{Análise estatistica}

O delineamento experimental utilizado foi 0 Quadrado Latino $4 \times 4$ (quatro animais e quatro subperiodos experimentais).

Os dados obtidos de consumo, eficiência alimentar, produção $e$ composição de leite, digestibilidade de nutrientes foram analisados utilizandose o PROC GLM (general linear model) do pacote estatístico SAS (1991).

Já para os dados de parâmetros ruminais e sanguíneos, utilizou-se 0 PROC MIXED do mesmo programa estatístico. Para tanto, os efeitos de tratamento, animal e periodo foram testados com relação às parcelas. 0 horário de coleta (tempo) e a interação tempo $x$ tratamento foram testados com relação às subparcelas.

Considerou-se o nível de $5 \%$ como significativo e até $15 \%$ como tendência para a probalidade do teste $F$ na análise de variância.

Somente após detectadas respostas significativas é que foi realizado o desdobramento da análise estatística, através do método dos quadrados mínimos (LSMEANS) para se verificar as diferenças entre os tratamentos para as diversas variáveis.

Os resumos dos quadros de análise de variância estão apresentados nas Tabelas 2 e 3.

Os parâmetros ruminais $(\mathrm{pH}$, concentração de amônia, concentração molar total dos AGV, porcentagens molares de acetato, propionato, butirato, isobutirato, isovalerato, valerato e relação acetato:propionato) foram analisados dentro dos tempos de coleta $0,4,8,12,16$ e 20 horas e os parâmetros 
sanguíneos (uréia e glucose plasmática), dentro dos tempos de coleta $0,2,4$, 6,12 e 18 horas.

Tanto para os parâmetros ruminais como para os sanguineos considerou-se o horário de fornecimento matinal de alimento como o tempo zero.

Tabela 2. Resumo esquemático da análise de variância para consumo de MS, eficiência alimentar, produção e composição do leite e digestibilidade dos nutrientes.

\begin{tabular}{lc}
\hline CAUSAS DE VARIAÇÃO & GRAUS DE LIBERDADE \\
\hline Animal & 3 \\
Período & 3 \\
Tratamento & 3 \\
Resíduo & 6 \\
\hline TOTAL & $\mathbf{1 5}$ \\
\hline
\end{tabular}

Tabela 3. Análise de variância para os parâmetros ruminais e sanguíneos.

\begin{tabular}{lc}
\hline CAUSAS DE VARIAÇÃO & GRAUS DE LIBERDADE \\
\hline Animal & 3 \\
Periodo & 3 \\
Tratamento & 3 \\
Residuo A & 6 \\
\hline Sub TOTAL & $\mathbf{1 5}$ \\
\hline Tempo & 5 \\
Tempo $\times$ Tratamento & 15 \\
Resíduo B & 60 \\
\hline TOTAL & $\mathbf{9 5}$ \\
\hline
\end{tabular}




\section{RESULTADOS}

\subsection{Consumo de matéria seca, matéria orgânica e nutrientes}

Os dados relativos ao consumo de MS, MO e dos demais nutrientes estão apresentados na Tabela 4.

Tabela 4. Valores médios de consumo de matéria seca, matéria orgânica e nutrientes.

\begin{tabular}{|c|c|c|c|c|c|c|}
\hline \multirow{3}{*}{ Consumo } & \multicolumn{4}{|c|}{ TRATAMENTOS } & \multirow[b]{3}{*}{ EPM $^{1}$} & \multirow[b]{3}{*}{$\operatorname{Pr}=F^{2}$} \\
\hline & \multicolumn{2}{|c|}{$10,05 \% \mathrm{~PB}$} & \multicolumn{2}{|c|}{$13,70 \%$ PB } & & \\
\hline & A & $B$ & C & D & & \\
\hline MS $(\mathrm{kg} / \mathrm{d})$ & 14,80 & 15,24 & 16,63 & 16,88 & 1,53 & 0,7378 \\
\hline$M O(\mathrm{~kg} / \mathrm{d})$ & 13,96 & 14,39 & 15,69 & 15,87 & 1,45 & 0,7512 \\
\hline$P B(\mathrm{~kg} / \mathrm{d})$ & $1,49^{b}$ & $1,53^{b}$ & $2,26^{a}$ & $2,31^{a}$ & 0,17 & 0,0348 \\
\hline$E E(\mathrm{~kg} / \mathrm{d})$ & 0,46 & 0,49 & 0,51 & 0,49 & 0,05 & 0,9233 \\
\hline $\mathrm{FDN}(\mathrm{kg} / \mathrm{d})$ & 6,14 & 6,41 & 6,84 & 6,79 & 0,64 & 0,8587 \\
\hline FDA (kg/d) & 3,26 & 3,36 & 3,64 & 3,71 & 0,34 & 0,7606 \\
\hline Amido $(\mathrm{kg} / \mathrm{d})$ & 5,50 & 5,93 & 5,46 & 5,88 & 0,11 & 0,9972 \\
\hline
\end{tabular}

1 Erro padrão da média

2 Probabilidade de haver efeito significativo dentre as dietas experimentais

ab Média na mesma linha seguidas de letras distintas diferem entre si a $5 \%$ de significância

Não houve efeito $(P>0,05)$ de tratamentos sobre o consumo de MS e MO. Entretanto, nos tratamentos com teores mais elevados de PB ( $C$ e $D)$, os valores numéricos de consumo de MS e MO foram superiores aos dos tratamentos A e B. A ausência de diferença estatística provavelmente se deve 
ao fato do erro padrão da média ter sido muito alto $(1,53$ e 1,45, respectivamente).

O aumento no teor de PB na dieta levou a um aumento $(P<0,05)$ no consumo deste nutriente.

Quanto aos consumos de EE, FDN, FDA e amido, os resultados obtidos demonstraram não haver efeito significativo $(P>0,05)$ de tratamentos sobre tais variáveis.

\subsection{Produção e composição de leite}

Os resultados de eficiência alimentar, produção de leite e composição do leite estão ilustrados na Tabela 5.

A produção de leite e de LCG a $3,5 \%$ não foram afetados $(P>0,05)$ pelos tratamentos utilizados, entretanto, numericamente os valores de produção acompanharam os valores para consumo de MS, ou seja, as produções foram mais elevadas para os tratamentos $C$ e $D(13,70 \% P B)$.

$O$ teor de gordura no leite foi maior $(P<0,05)$ no tratamento $B$ em relação aos demais, porém a produção $(\mathrm{kg} / \mathrm{dia})$ de gordura não foi afetada $(P>0,05)$ pelos tratamentos.

Não houve diferença $(P>0,05)$ entre os tratamentos para os teores e as produções de proteína, lactose e sólidos totais do leite, assim como para a relação gordura/proteína.

A eficiência de conversão de proteina da dieta em proteína do leite, não foi afetada $(P>0,05)$ pelos tratamentos, apesar de valores numericamente mais altos para os tratamentos com $10,05 \%$ de PB (A e B). A eficiência alimentar também não foi afetada $(P>0,05)$ pelos tratamentos. 
Tabela 5. Valores médios de consumo de MS, produção, composição, relação gordura/proteína e eficiência alimentar.

\begin{tabular}{|c|c|c|c|c|c|c|}
\hline \multirow{3}{*}{ Parâmetro } & \multicolumn{4}{|c|}{ TRATAMENTOS } & \multirow[b]{3}{*}{$\mathrm{EPM}^{6}$} & \multirow[b]{3}{*}{$\mathrm{Pr}=\mathrm{F}^{7}$} \\
\hline & \multicolumn{2}{|c|}{$10,05 \% \mathrm{~PB}$} & \multicolumn{2}{|c|}{$13,70 \% \mathrm{~PB}$} & & \\
\hline & A & $B$ & $\mathrm{C}$ & $\mathrm{D}$ & & \\
\hline Consumo MS (kg/d) & 14,80 & 15,24 & 16,63 & 16,88 & 1,53 & 0,7378 \\
\hline $\begin{array}{l}\mathrm{PL}, \text { total }(\mathrm{kg} / \mathrm{d})^{1} \\
{ }^{1} \text { corrigido }(\mathrm{kg} / \mathrm{d})^{2}\end{array}$ & $\begin{array}{l}11,91 \\
12,54\end{array}$ & $\begin{array}{l}11,23 \\
12,01\end{array}$ & $\begin{array}{l}12,22 \\
12,90\end{array}$ & $\begin{array}{l}13,17 \\
13,63\end{array}$ & $\begin{array}{l}0,88 \\
1,02\end{array}$ & $\begin{array}{l}0,5224 \\
0,7273\end{array}$ \\
\hline Gordura , \% & $\begin{array}{l}3,77^{b} \\
0,45^{b}\end{array}$ & $\begin{array}{l}4,04^{a} \\
0,44\end{array}$ & $\begin{array}{l}3,80^{b} \\
0,47^{b}\end{array}$ & $\begin{array}{l}3,78^{b} \\
0,49\end{array}$ & $\begin{array}{l}0,04 \\
0,04\end{array}$ & $\begin{array}{l}0,0145 \\
0,8451\end{array}$ \\
\hline Proteína, \% & $\begin{array}{l}3,68 \\
0,44\end{array}$ & $\begin{array}{l}3,76 \\
0,42\end{array}$ & $\begin{array}{l}3,82 \\
0,47\end{array}$ & $\begin{array}{l}3,77 \\
0,50\end{array}$ & $\begin{array}{l}0,08 \\
0,03\end{array}$ & $\begin{array}{l}0,7262 \\
0,3913\end{array}$ \\
\hline $\begin{aligned} \text { Lactose } & \% \\
& , \mathrm{~kg} / \mathrm{d}\end{aligned}$ & $\begin{array}{l}4,58 \\
0,54\end{array}$ & $\begin{array}{l}4,44 \\
0,50\end{array}$ & $\begin{array}{l}4,52 \\
0,55\end{array}$ & $\begin{array}{l}4,59 \\
0,60\end{array}$ & $\begin{array}{l}0,07 \\
0,05\end{array}$ & $\begin{array}{l}0,4921 \\
0,5212\end{array}$ \\
\hline $\begin{array}{r}\text { Sólidos totais, } \% \\
, \mathrm{~kg} / \mathrm{d}\end{array}$ & $\begin{array}{r}12,68 \\
1,51\end{array}$ & $\begin{array}{r}12,86 \\
1,43\end{array}$ & $\begin{array}{r}12,77 \\
1,56\end{array}$ & $\begin{array}{r}12,79 \\
1,67\end{array}$ & $\begin{array}{l}0,06 \\
0,12\end{array}$ & $\begin{array}{l}0,3172 \\
0,5783\end{array}$ \\
\hline Gordura / Proteina ${ }^{3}$ & 1,02 & 1,07 & 0,99 & 1,00 & 0,03 & 0,4181 \\
\hline Efic. de conversão $\mathrm{PB}^{4}$ & 290,83 & 281,24 & 221,28 & 213,78 & 31,50 & 0,3116 \\
\hline Efic. Alimentar ${ }^{5}$ & 0,84 & 0,81 & 0,82 & 0,81 & 0,10 & 0,9972 \\
\hline \multicolumn{7}{|l|}{ Produção de leite } \\
\hline \multicolumn{7}{|c|}{2 Produção de leite corrigido para $3,5 \%$ de gordura } \\
\hline \multicolumn{7}{|c|}{3 Relaçäo entre produção de gordura e proteína do leite } \\
\hline \multicolumn{7}{|c|}{4 Eficiència de conversão da proteína consumida $(\mathrm{kg})$ em proteína do leite $(\mathrm{g})$} \\
\hline \multicolumn{7}{|c|}{5 Eficiência alimentar - $\mathrm{kg}$ leite corrigido a $3,5 \% / \mathrm{kg}$ MS consumida } \\
\hline \multicolumn{7}{|c|}{6 Erro padrão da média } \\
\hline \multicolumn{7}{|c|}{7 Probabilidade de haver efeito significativo dentre as dietas experimentais } \\
\hline ab Média seguidas de letra & is distintas d & ferem entre & $5 \%$ de sigr & ificância & & \\
\hline
\end{tabular}

\subsection{Parâmetros ruminais}

\subsubsection{Concentração de nitrogênio amoniacal no rúmen}

Os dados resultantes da análise de concentração de $\mathrm{N}$-amoniacal no rúmen constam na Tabela 6 . A Figura 1 ilustra a variação durante o dia do acúmulo de amônia no líquido ruminal, conforme os tratamentos. 
Tabela 6. Valores de quadrados mínimos da concentração de amônia ruminal $(\mathrm{mg} / \mathrm{dL})$

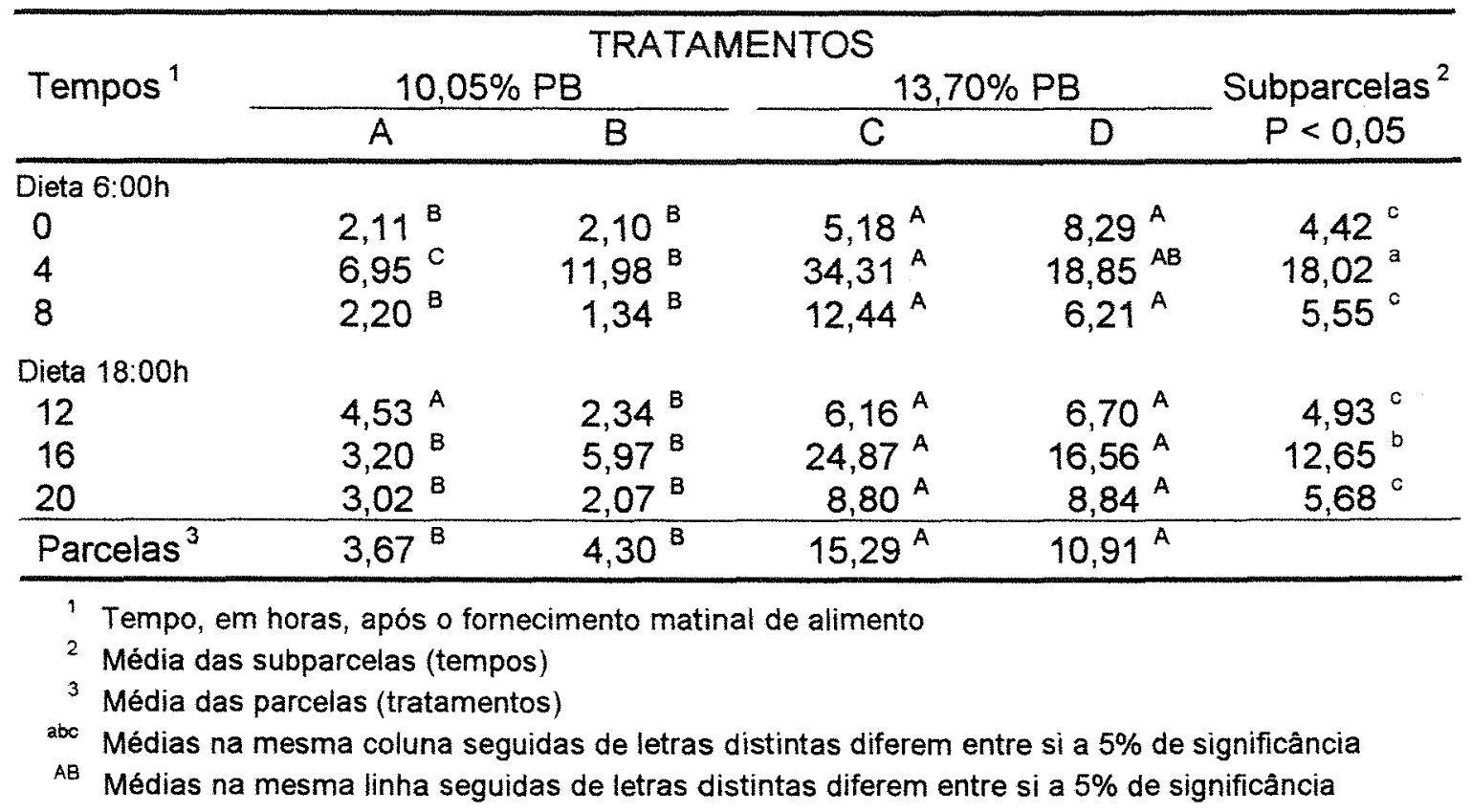

Os valores médios observados na concentração de amônia ruminal no momento do fornecimento da alimentação foram 4,42 e 4,93 $\mathrm{mg} / \mathrm{dL}$, respectivamente, para o fornecimento matutino e vespertino. A concentração aumentou $(\mathrm{P}<0,05)$ quatro horas após o fornecimento da dieta, tanto da manhã quanto do final da tarde.

As dietas que continham teores maiores de PB na MS levaram os animais a produzirem uma maior $(P<0,05)$ concentração ruminal de amônia, provavelmente pelo fato do consumo de PB pelos animais submetidos a esses tratamentos ter sido maior, conforme mostrado na Tabela 4.

Houve diferença $(P>0,05)$ também na interação tratamento $x$ tempo.

A concentração de amônia no rúmen não foi alterada $(P>0,05)$ quando se comparou as dietas com os mesmos teores de PB, ou seja, a fonte de proteína, uréia $x$ farelo de soja, não afetou este parâmetro analisado. 


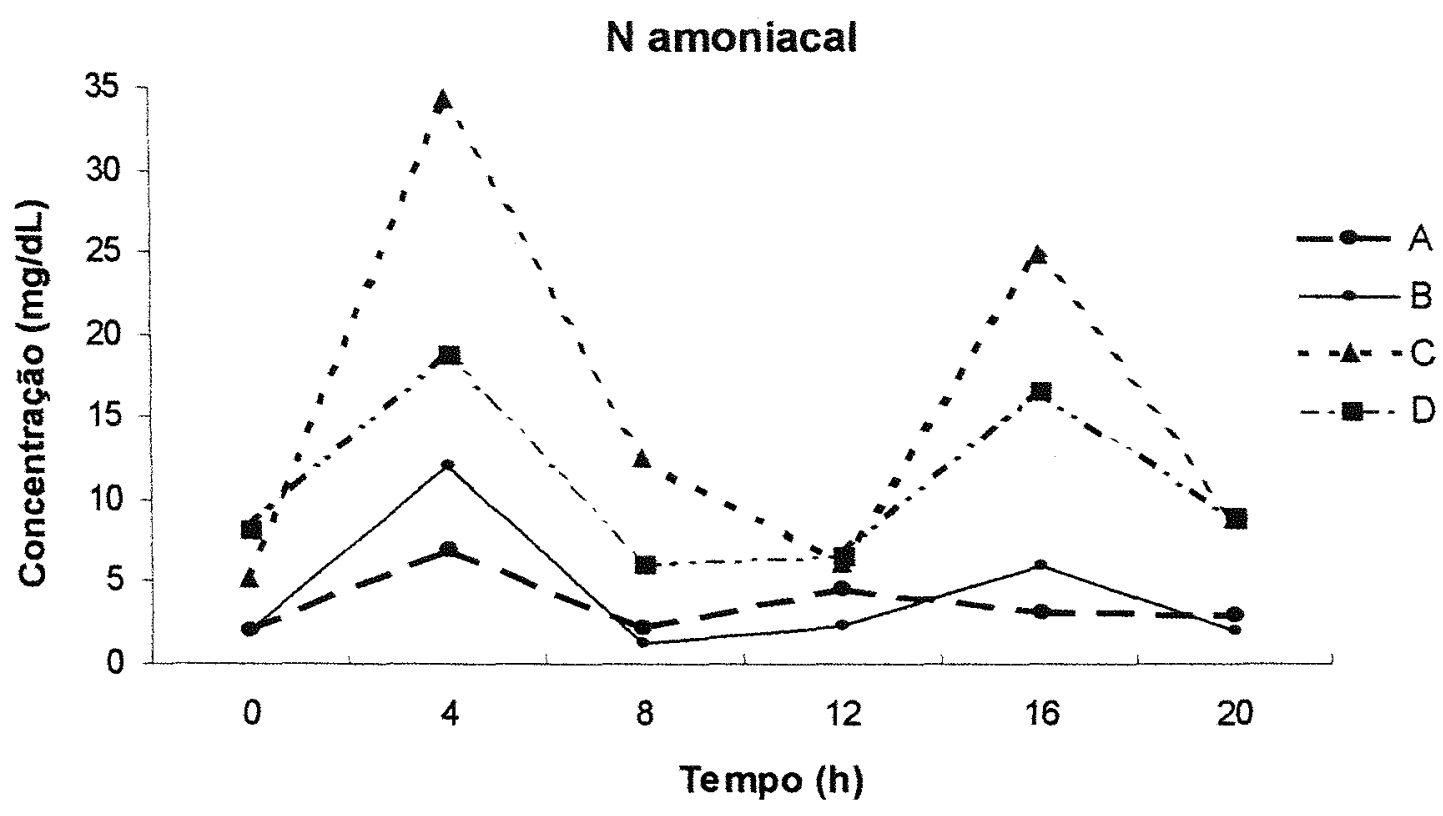

Figura 1. Efeito das dietas experimentais sobre a concentração de nitrogênio amoniacal no rúmen nos diferentes horários de amostragem em relação ao fornecimento matinal de alimento.

\subsection{2 $\mathrm{pH}$ ruminal}

Os dados resultantes da leitura de $\mathrm{pH}$ ruminal estão apresentados na Tabela 7 e Figura 2.

Houve diferença $(P<0,05)$ de $\mathrm{pH}$ ruminal entre os tratamentos nos tempos de coleta 0,4 e 12 horas, com valores mais baixos para os tratamentos $C$ e D. Entretanto, não houve diferença $(P>0,05)$ entre os valores médios diários de $\mathrm{pH}$ de cada tratamento (parcelas). A Figura 2 ilustra a variação do $\mathrm{pH}$ ruminal e mostra que os tratamentos apresentaram variações similares de pH durante o transcorrer do dia.

$\mathrm{O}$ pH variou $(\mathrm{P}<0,05)$ entre os valores médios de cada tempo de coleta (subparcelas) e teve seus maiores valores médios no momento anterior ao fornecimento do alimento da manhã e da tarde $(6,33$ e 6,43, respectivamente). Os menores valores de $\mathrm{pH}$ ocorreram 8 horas após o fornecimento do alimento 
da manhã $(0,55$ unidades menor $)$ e 4 horas após o fornecimento do alimento da tarde $(0,73$ unidades menor $)$.

Tabela 7. Valores de quadrados mínimos do $\mathrm{pH}$ ruminal

\begin{tabular}{|c|c|c|c|c|c|}
\hline \multirow{3}{*}{ Tempos $^{1}$} & \multicolumn{4}{|c|}{ TRATAMENTOS } & \multirow{3}{*}{$\begin{array}{c}\text { Subparcelas }^{2} \\
P<0,05\end{array}$} \\
\hline & \multicolumn{2}{|c|}{$10,05 \% \mathrm{~PB}$} & \multicolumn{2}{|c|}{$13,70 \% \mathrm{~PB}$} & \\
\hline & A & $B$ & C & D & \\
\hline Dieta 6:00h & & & & & \\
\hline 0 & $6,52^{A}$ & $6,54^{\mathrm{A}}$ & $6,08^{B}$ & $6,19^{\mathrm{B}}$ & $6,33^{\mathrm{a}}$ \\
\hline 4 & $5,89^{A B}$ & $5,88^{A B}$ & $6,12^{A}$ & $5,81^{\mathrm{B}}$ & $5,92^{b}$ \\
\hline 8 & 5,89 & 5,84 & 5,65 & 5,75 & $5,78^{\circ}$ \\
\hline Dieta $18: 00 \mathrm{~h}$ & & & & & \\
\hline 12 & $6,47^{A B}$ & $6,56^{\mathrm{A}}$ & $6,30^{B}$ & $6,41^{A B}$ & $6,43^{a}$ \\
\hline 16 & 5,78 & 5,61 & 5,67 & 5,74 & $5,70^{\circ}$ \\
\hline 20 & 6,12 & 6,14 & 5,94 & 5,90 & $6,02^{b}$ \\
\hline Parcelas $^{3}$ & 6,11 & 6,09 & 5,96 & 5,97 & \\
\hline
\end{tabular}

1 Tempo, em horas, após o fornecimento matinal de alimento

2 Média das subparcelas (tempos)

3 Média das parcelas (tratamentos)

abc Médias na mesma coluna seguidas de letras distintas diferem entre si a $5 \%$ de significancia

AB Médias na mesma linha seguidas de letras distintas diferem entre si a $5 \%$ de significância 


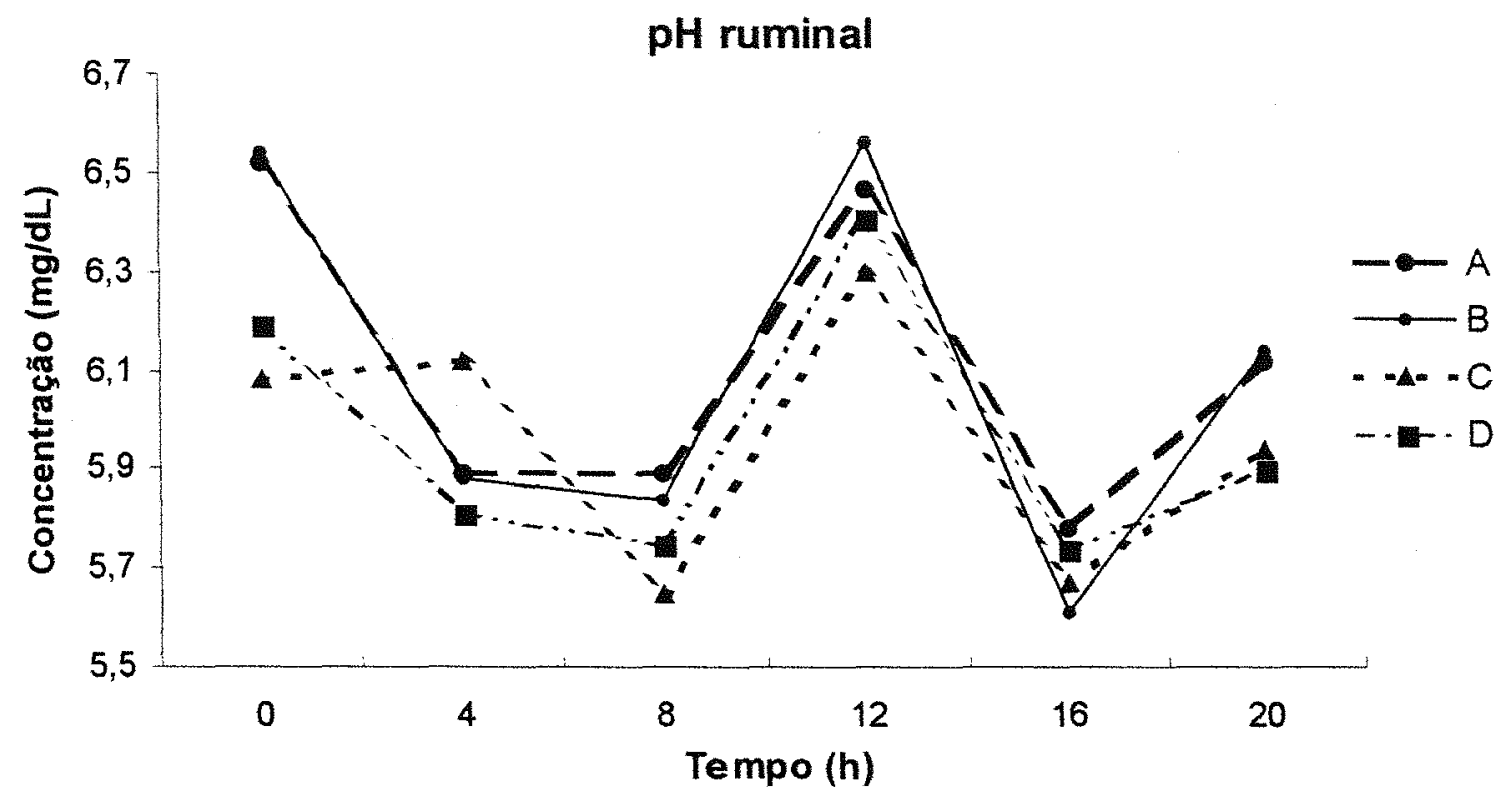

Figura 2. Efeito das dietas experimentais sobre o pH ruminal nos diferentes horários de amostragem em relação ao fornecimento matinal de alimento.

\subsection{3 Ácidos graxos voláteis}

\subsubsection{1 Ácidos graxos voláteis totais}

Os dados resultantes da análise de AGV totais estão apresentados na Tabela 8 e Figura 3.

Não houve diferença $(P>0,05)$ na interação tratamento $x$ tempo.

A concentração total de AGV no líquido ruminal variou $(P<0,10)$ entre os valores médios de cada tempo de coleta (subparcelas). No momento do fornecimento da dieta, observou-se concentrações médias de 88,70 e 85,14 $\mathrm{mM}$ nas coletas realizadas de manhã e de tarde, respectivamente, sendo que o maior acúmulo de AGV ocorreu em torno de 8 horas após o fornecimento da dieta na parte da manhã e após 4 horas na parte da tarde $(97,28$ e 103,74, respectivamente). 
As dietas com maior teor de PB levaram os animais a produzirem maiores $(P<0,05)$ concentrações médias diárias de AGV totais, sugerindo que tais dietas permitiram uma maior fermentação da matéria orgânica pelos microorganismos ruminais.

No presente experimento, comparando-se tratamentos dentro de um mesmo teor de PB na dieta, observou-se que a substituição de farelo de soja por uréia levou as vacas a produzirem concentrações molares de AGV no fluido ruminal similares $(P>0,05)$.

Tabela 8. Valores de quadrados mínimos da concentração total de AGV no rúmen $(\mathrm{mM})$

\begin{tabular}{|c|c|c|c|c|c|}
\hline \multirow{3}{*}{ Tempos $^{1}$} & \multicolumn{4}{|c|}{ TRATAMENTOS } & \multirow{3}{*}{$\begin{array}{c}\text { Subparcelas }^{2} \\
P<0,05\end{array}$} \\
\hline & \multicolumn{2}{|c|}{$10,05 \% \mathrm{~PB}$} & \multicolumn{2}{|c|}{$13,70 \%$ PB } & \\
\hline & A & $\mathrm{B}$ & $\mathrm{C}$ & $\mathrm{D}$ & \\
\hline \multicolumn{6}{|l|}{ Dieta 6:00h } \\
\hline 0 & 82,29 & 75,84 & 100,27 & 96,42 & $88,70^{b}$ \\
\hline 4 & 87,69 & 87,19 & 105,30 & 99,89 & $95,02^{a b}$ \\
\hline 8 & 102,58 & 70,00 & 104,93 & 111,60 & $97,28^{a b}$ \\
\hline \multicolumn{6}{|l|}{ Dieta $18: 00 \mathrm{~h}$} \\
\hline 12 & 85,96 & 69,90 & 86,66 & 98,04 & $85,14^{b}$ \\
\hline 16 & 91,25 & 97,42 & 123,14 & 103,15 & $103,74^{a}$ \\
\hline 20 & 98,89 & 86,65 & 101,70 & 97,73 & $96,17^{a b}$ \\
\hline Parcelas $^{3}$ & $91,44^{\mathrm{B}}$ & $81,16^{8}$ & $103,67^{\mathrm{A}}$ & $101,09^{A}$ & \\
\hline
\end{tabular}

1 Tempo, em horas, após o fornecimento matinal de alimento

2 Média das subparcelas (tempos)

3 Média das parcelas (tratamentos)

abc Médias na mesma coluna seguidas de letras distintas diferem entre si a $10 \%$ de significância

AB Médias na mesma linha seguidas de letras distintas diferem entre si a $5 \%$ de significância 


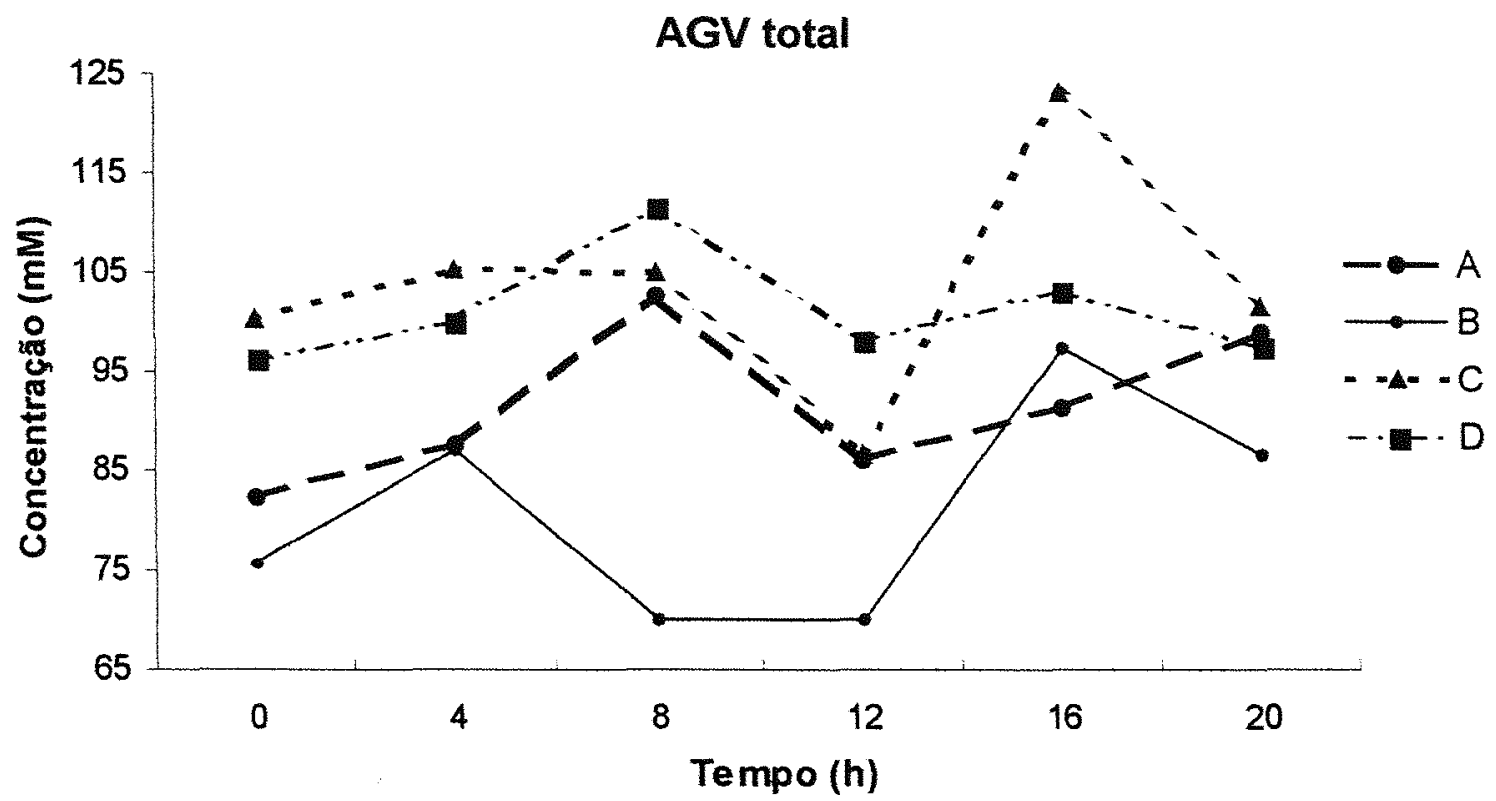

Figura 3. Efeito das dietas experimentais sobre a concentração molar total de ácidos graxos voláteis no rúmen nos diferentes horários de amostragem em relação ao fornecimento matinal de alimento.

\subsubsection{2 Ácido acético}

Os dados resultantes da análise da porcentagem molar de acetato estão apresentados na Tabela 9 e Figura 4.

Não houve interação tratamento $x$ tempo $(P>0,05)$ para a porcentagem molar de acetato no fluido ruminal.

A concentração molar de acetato em relação ao total de AGV no liquido ruminal variou $(P<0,15)$ entre os valores médios de cada tempo de coleta (subparcelas). No momento do fornecimento da dieta, observou-se porcentagens molares médias de 66,51 e $65,33 \%$ nas coletas realizadas de manhã e de tarde, respectivamente. 
Tabela 9. Valores de quadrados mínimos da porcentagem de acetato em relação ao total de AGV no rúmen

\begin{tabular}{|c|c|c|c|c|c|}
\hline \multirow{3}{*}{ Tempos $^{1}$} & \multicolumn{4}{|c|}{ TRATAMENTOS } & \multirow{3}{*}{$\begin{array}{c}\text { Subparcelas }^{2} \\
P<0,05\end{array}$} \\
\hline & \multicolumn{2}{|c|}{$10,05 \% \mathrm{~PB}$} & \multicolumn{2}{|c|}{$13,70 \%$ PB } & \\
\hline & $A$ & $B$ & C & $D$ & \\
\hline \multicolumn{6}{|l|}{ Dieta 6:00h } \\
\hline 0 & 68,63 & 67,52 & 65,05 & 64,86 & $66,51^{\mathrm{a}}$ \\
\hline 4 & 68,08 & 66,87 & 66,14 & 64,37 & $66,37^{2}$ \\
\hline 8 & 66,82 & 66,37 & 62,91 & 63,42 & $64,88^{b}$ \\
\hline \multicolumn{6}{|l|}{ Dieta $18: 00 \mathrm{~h}$} \\
\hline 12 & 67,19 & 67,04 & 64,51 & 62,58 & $65,33^{a b}$ \\
\hline 16 & 67,04 & 68,15 & 63,36 & 64,68 & $65,81^{a b}$ \\
\hline 20 & 68,34 & 69,03 & 63,81 & 65,64 & $66,71^{\mathrm{a}}$ \\
\hline Parcelas ${ }^{3}$ & $67,68^{\mathrm{A}}$ & $67,50^{A}$ & $64,30^{B}$ & $64,26^{\mathrm{B}}$ & \\
\hline
\end{tabular}

1 Tempo, em horas, após o fornecimento matinal de alimento

2 Média das subparcelas (tempos)

3 Média das parcelas (tratamentos)

ab Médias na mesma coluna seguidas de letras distintas diferem entre si a $15 \%$ de significância

AB Médias na mesma linha seguidas de letras distintas diferem entre si a $5 \%$ de significância

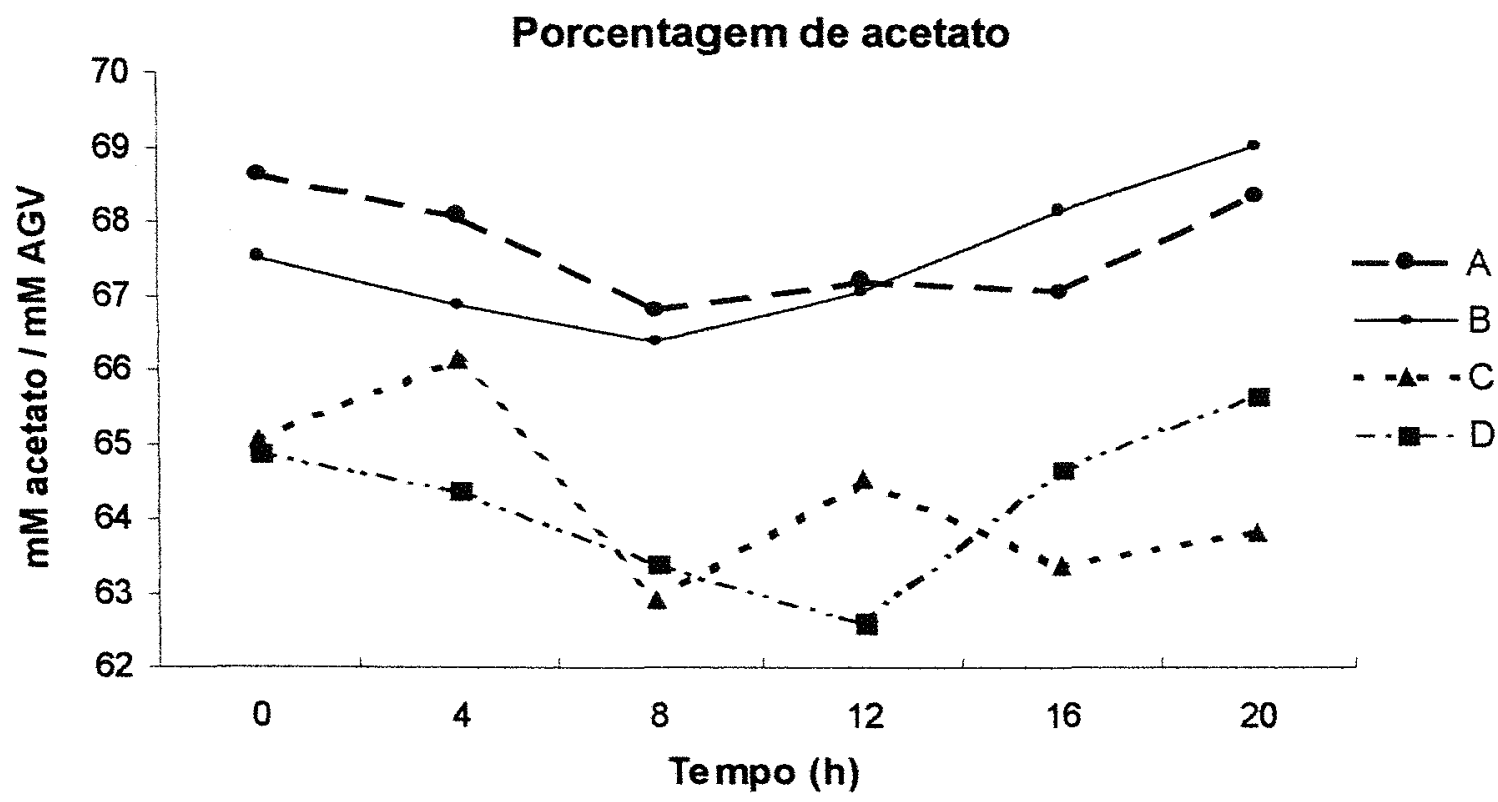

Figura 4. Efeito das dietas experimentais sobre a porcentagem molar de acetato no rúmen nos diferentes horários de amostragem em relação ao fornecimento matinal de alimento. 
As dietas com menor teor de PB ( $\mathrm{A}$ e $\mathrm{B})$ resultaram em maiores $(P<0,05)$ porcentagens molares de acetato no fluido ruminal.

A substituição de farelo de soja por uréia resultou em porcentagens molares de acetato no líquido ruminal similares $(P>0,05)$.

\subsubsection{3 Ácido propiônico}

Os dados resultantes da análise da concentração de propionato em relação ao total de AGV estão apresentados na Tabela 10 e Figura 5.

Tabela 10. Valores de quadrados mínimos da porcentagem de propionato em relação ao total de AGV no rúmen.

\begin{tabular}{|c|c|c|c|c|c|}
\hline & & TR & JTOS & & \\
\hline Tempos ${ }^{1}$ & & & & & Subparcelas $^{2}$ \\
\hline & $A$ & $B$ & $\mathrm{C}$ & $D$ & $P<0,05$ \\
\hline Dieta 6:00 h & & & & & \\
\hline 0 & 17,19 & 17,05 & 19,12 & 19,59 & $18,24^{b}$ \\
\hline 4 & 19,16 & 19,81 & 19,73 & 20,40 & $19,77^{a}$ \\
\hline 8 & 19,20 & 18,49 & 20,29 & 20,31 & $19,57^{\mathrm{a}}$ \\
\hline Dieta $18: 00 \mathrm{~h}$ & & & & & \\
\hline 12 & 19,00 & 17,74 & 19,19 & 21,15 & $19,27^{a}$ \\
\hline 16 & 19,36 & 18,54 & 20,67 & 20,02 & $19,65^{a}$ \\
\hline 20 & 17,48 & 17,05 & 18,38 & 19,53 & $18,11^{b}$ \\
\hline Parcelas $^{3}$ & 18,57 & 18,11 & 19,56 & 20,16 & \\
\hline 1 Temp & horas, & necim & de alim & & \\
\hline 2 Média & subparo & pos) & & & \\
\hline 3 Média & parcelas & entos) & & & \\
\hline ab Média & mesma & guida & ctintas & & ncia \\
\hline
\end{tabular}

Não houve interação tratamento $x$ tempo $(P>0,05)$ para a porcentagem molar de propionato no fluido ruminal.

Houve efeito $(P<0,05)$ do tempo de coleta (subparcelas) na porcentagem molar média de propionato no fluido ruminal, com valores 
inferiores nos tempos 0 e 20 horas. No momento do fornecimento da dieta, observou-se porcentagens molares médias de 18,24 e 19,27\% nas coletas realizadas de manhã e de tarde, respectivamente.

Os tratamentos (parcelas), fonte ou teor de proteina, não afetaram $(P>0,05)$ a porcentagem molar de propionato no rúmen.

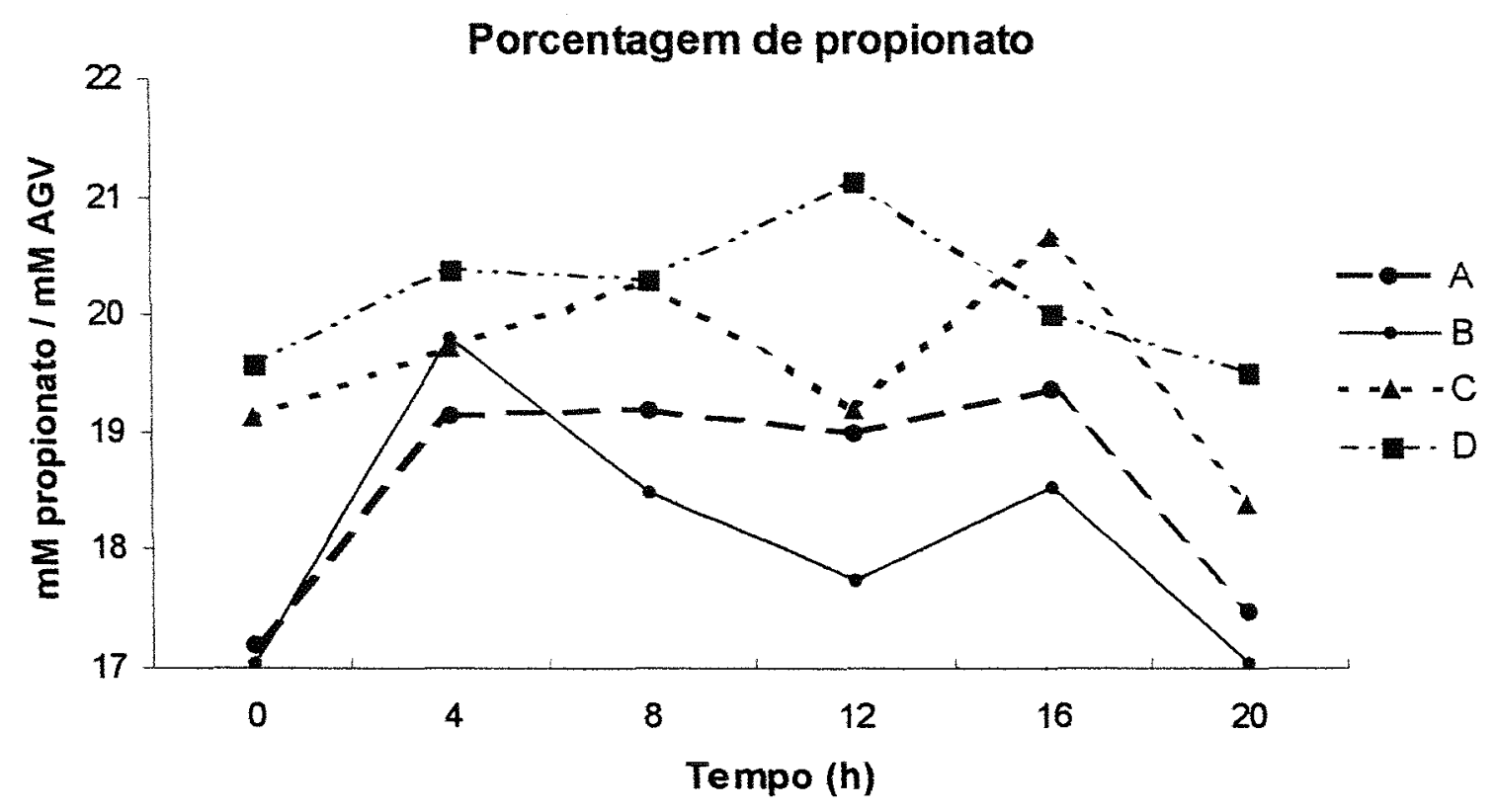

Figura 5. Efeito das dietas experimentais sobre a porcentagem molar de propionato no rúmen nos diferentes horários de amostragem em relação ao fornecimento matinal de alimento.

\subsubsection{4 Ácido butírico}

Os dados resultantes da análise da concentração de butirato em relação ao total de AGV estão apresentados na Tabela 11 e Figura 6.

Não houve interação $(P>0,05)$ entre tratamento $x$ tempo para a porcentagem de butirato no fluido ruminal. 
Houve efeito $(P<0,05)$ do tempo de coleta (subparcelas) na porcentagem média de butirato no fluido ruminal, com os valores mais baixos ocorrendo nos tempos 4 e 20 horas. No momento do fornecimento da dieta, observou-se porcentagens molares médias de $10,48 \%$ nas coletas realizadas tanto de manhã quanto de tarde.

As dietas com maior teor de PB (C e D) apresentaram valores mais altos $(P<0,10)$ de butirato no fluido ruminal quando comparadas com 0 tratamento $A$. Porém, não houve efeito $(P>0,05)$ da substituição de farelo de soja por uréia sobre a porcentagem molar de butirato.

Tabela 11. Valores de quadrados mínimos da porcentagem de butirato em relação ao total de AGV no rúmen.

\begin{tabular}{|c|c|c|c|c|c|}
\hline \multirow{3}{*}{ Tempos $^{1}$} & \multicolumn{4}{|c|}{ TRATAMENTOS } & \multirow{3}{*}{$\begin{array}{c}\text { Subparcelas } \\
\\
P<0,05\end{array}$} \\
\hline & \multicolumn{2}{|c|}{$10,05 \% \mathrm{~PB}$} & \multicolumn{2}{|c|}{$13,70 \% \mathrm{~PB}$} & \\
\hline & $A$ & $B$ & $\mathrm{C}$ & $\mathrm{D}$ & \\
\hline \multicolumn{6}{|l|}{ Dieta 6:00h } \\
\hline 0 & 9,19 & 10,34 & 11,46 & 10,94 & $10,48^{a b}$ \\
\hline 4 & 9,02 & 9,40 & 10,40 & 10,84 & $9,91^{b}$ \\
\hline 8 & 9,41 & 10,04 & 12,62 & 11,41 & $10,87^{\mathrm{a}}$ \\
\hline \multicolumn{6}{|l|}{ Dieta 18:00h } \\
\hline 12 & 9,03 & 9,84 & 11,97 & 11,10 & $10,48^{a b}$ \\
\hline 16 & 9,54 & 9,48 & 12,23 & 10,86 & $10,53^{a b}$ \\
\hline 20 & 8,93 & 9,55 & 11,61 & 10,51 & $10,15^{b}$ \\
\hline Parcelas $^{3}$ & $9,19^{c}$ & $9,78^{\mathrm{BC}}$ & $11,72^{A}$ & $10,94^{A B}$ & \\
\hline \multicolumn{6}{|c|}{1 Tempo, em horas, após o fornecimento matinal de alimento } \\
\hline \multicolumn{6}{|c|}{2 Média das subparcelas (tempos) } \\
\hline \multicolumn{6}{|c|}{3 Média das parcelas (tratamentos) } \\
\hline \multicolumn{6}{|c|}{ abc Médias na mesma coluna seguidas de letras distintas diferem entre si a $5 \%$ de significância } \\
\hline ABC Média & mesma lir & guidas de le & tintas difere & si a $10 \% d$ & significância \\
\hline
\end{tabular}




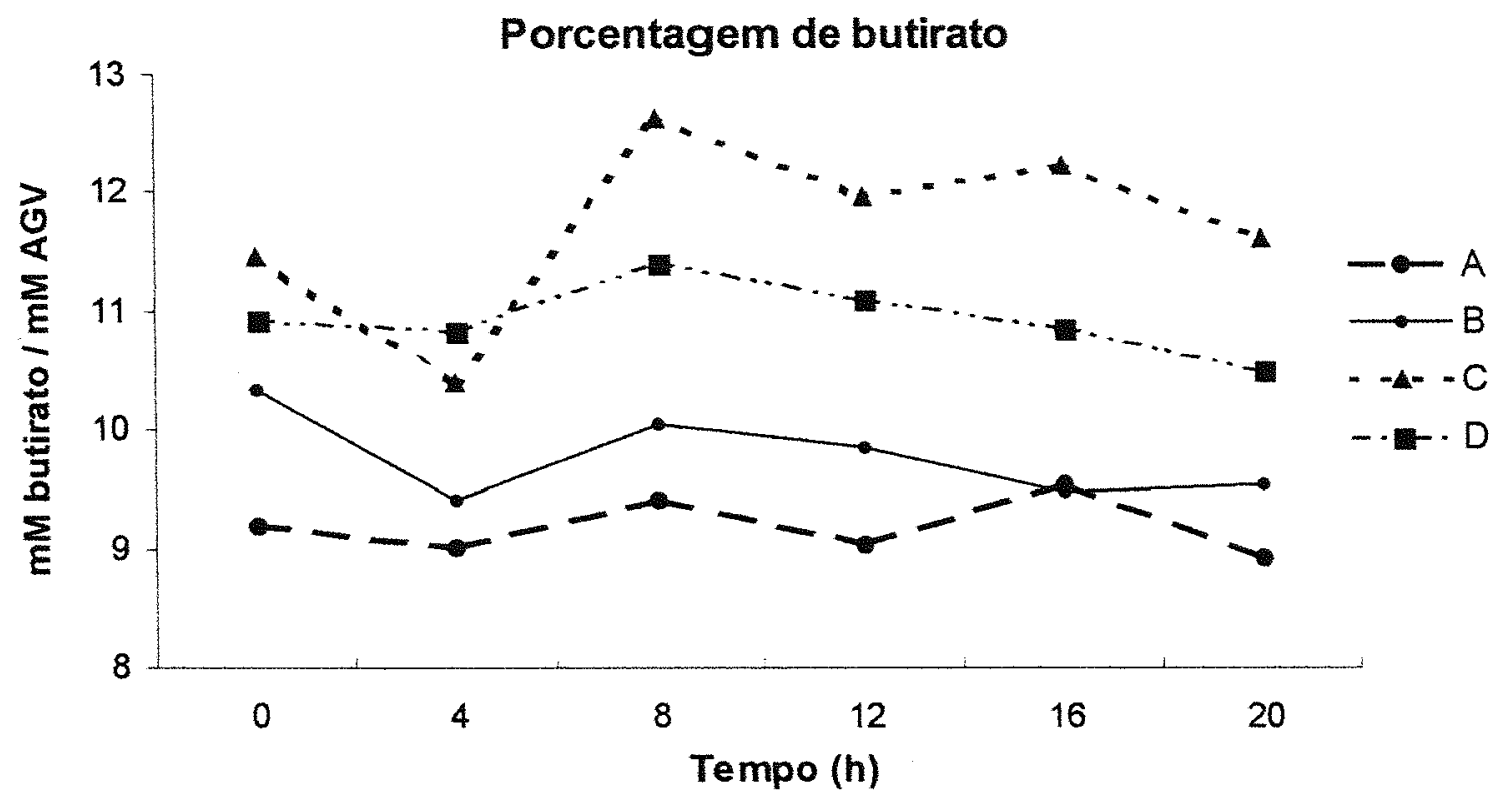

Figura 6. Efeito das dietas experimentais sobre a porcentagem molar de butirato no rúmen nos diferentes horários de amostragem em relação ao fornecimento matinal de alimento.

\subsubsection{Relação acetato/propionato}

Os dados referentes à análise da relação acetato/propionato estão apresentados na Tabela 12 e Figura 7.

Não houve interação $(P>0,05)$ tratamento $\times$ tempo para a relação acetato/propionato.

Houve efeito $(P<0,05)$ do tempo de coleta (subparcelas) sobre a relação acetato/propionato no fluido ruminal, com os valores mais elevados ocorrendo nos tempos 0 e 20 horas. No momento do fornecimento da dieta, observou-se relações de 3,71 e 3,46 nas coletas realizadas de manhã e de tarde, respectivamente.

Não foi observada diferença $(P>0,05)$ na relação acetato/propionato entre os valores médios diários de cada tratamento (parcelas). 
Tabela 12. Valores de quadrados mínimos da relação acetato:propionato produzidos no rúmen.

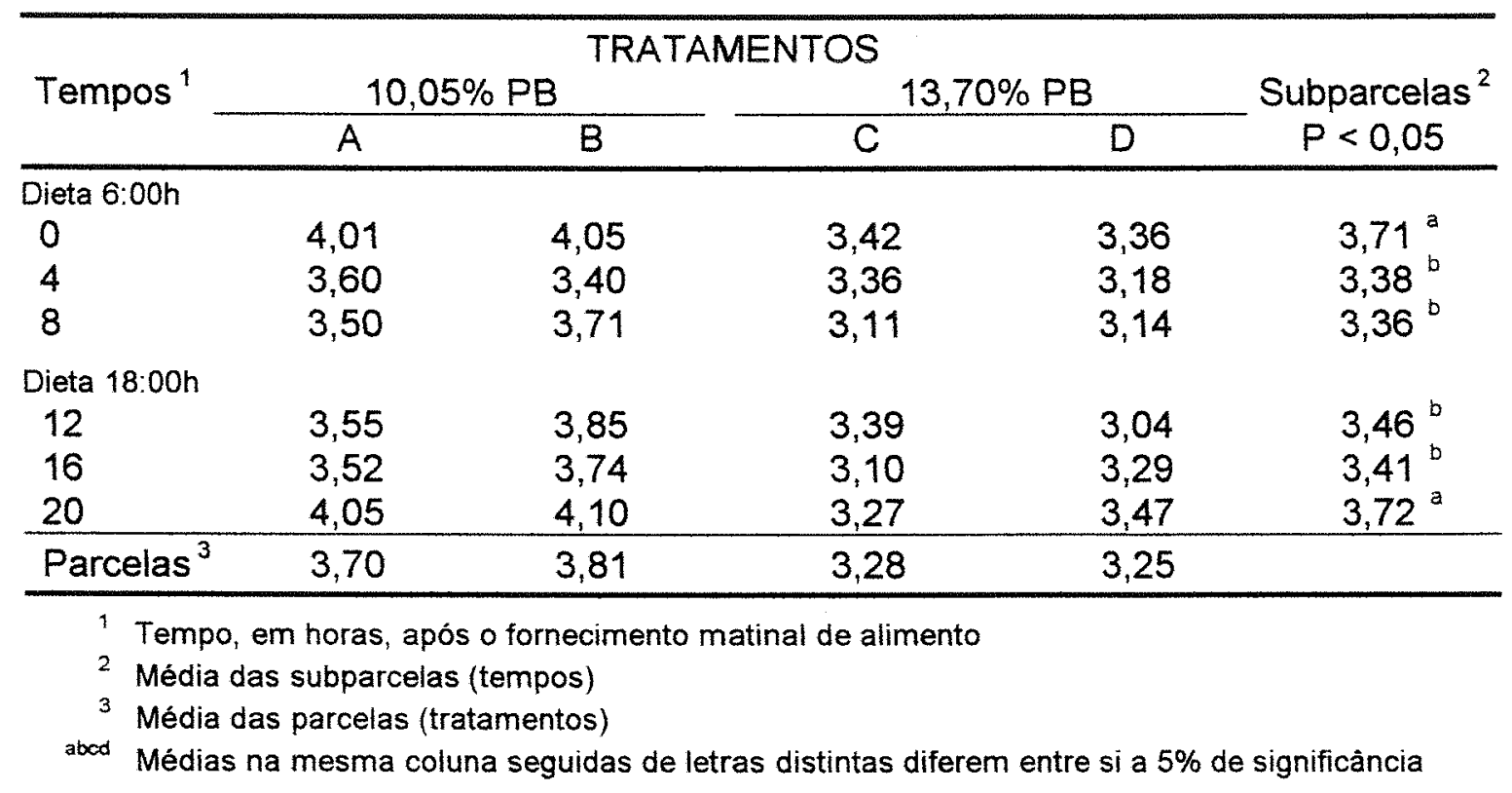

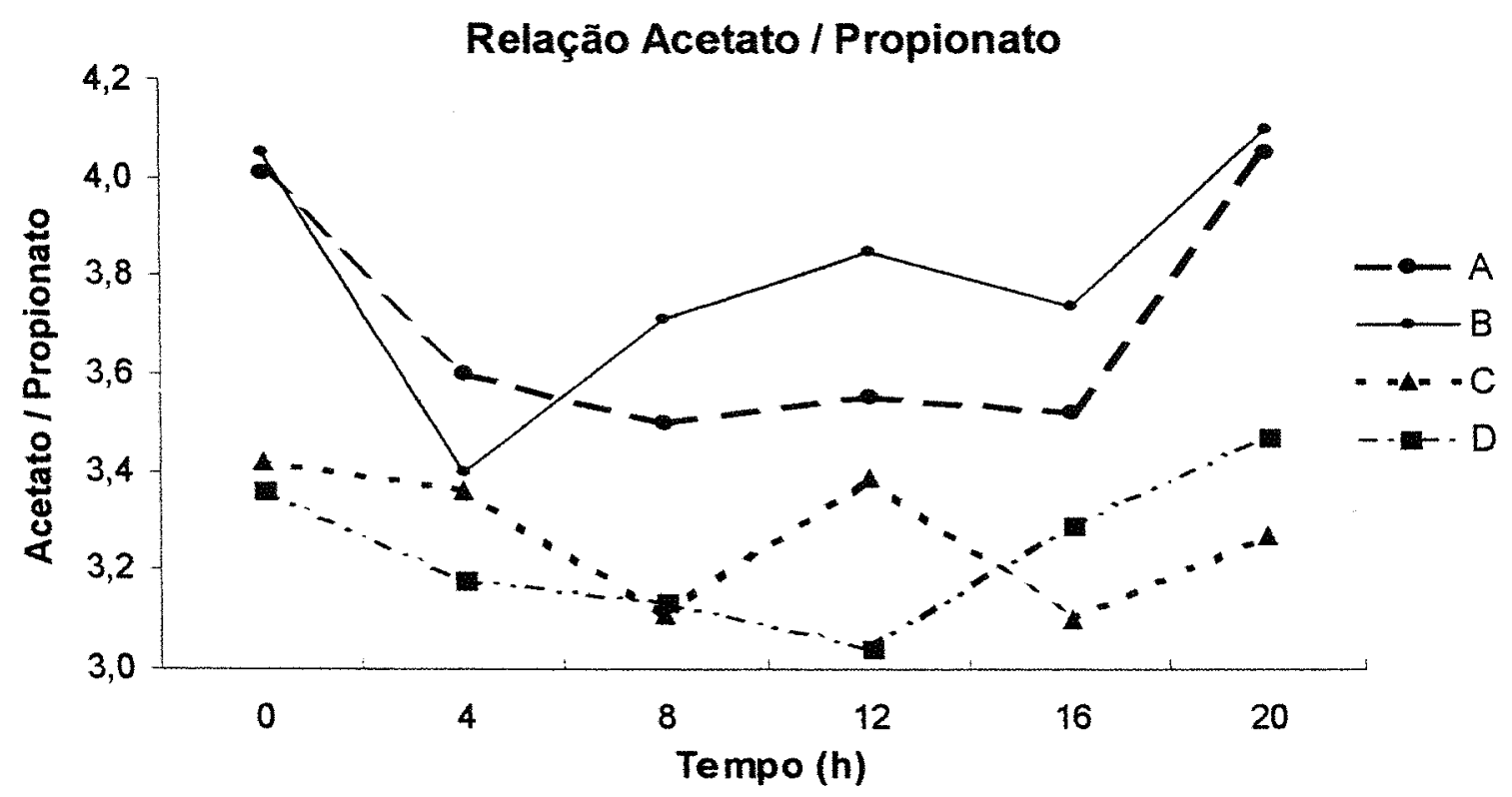

Figura 7. Efeito das dietas experimentais sobre a relação acetato/propionato nos diferentes horários de amostragem em relação ao fornecimento matinal de alimento. 


\subsubsection{6 Ácido isobutírico, isovalérico e valérico}

Os AGV de cadeia ramificada são produzidos após a digestão da proteína no rúmen, a partir da deaminação e descarboxilação de AA de cadeia ramificada (leucina, isoleucina e valina).

Os dados referentes à análise da porcentagem molar de isobutirato estão apresentados na Tabela 13 e Figura 8.

Tabela 13. Valores de quadrados mínimos da porcentagem de isobutirato em relação ao total de AGV no rúmen.

\begin{tabular}{|c|c|c|c|c|c|}
\hline \multirow{3}{*}{ Tempos $^{1}$} & \multicolumn{4}{|c|}{ TRATAMENTOS } & \multirow{3}{*}{$\begin{array}{c}\text { Subparcelas }^{2} \\
P<0,05\end{array}$} \\
\hline & \multicolumn{2}{|c|}{$10,05 \% \mathrm{~PB}$} & \multicolumn{2}{|c|}{$13,70 \% \mathrm{~PB}$} & \\
\hline & A & $B$ & $\mathrm{C}$ & $D$ & \\
\hline $\begin{array}{l}\text { Dieta 6:00h } \\
0 \\
4 \\
8\end{array}$ & $\begin{array}{l}1,02^{A} \\
0,62^{A B} \\
0,71^{A}\end{array}$ & $\begin{array}{l}1,00^{A} \\
0,53^{B} \\
0,55^{A B}\end{array}$ & $\begin{array}{l}0,69^{\mathrm{B}} \\
0,56^{\mathrm{AB}} \\
0,44^{\mathrm{B}}\end{array}$ & $\begin{array}{l}0,94^{A} \\
0,73^{A} \\
0,67^{A}\end{array}$ & $\begin{array}{l}0,91^{a} \\
0,61^{c} \\
0,59^{c}\end{array}$ \\
\hline $\begin{array}{l}\text { Dieta 18:00h } \\
12 \\
16 \\
20 \\
\end{array}$ & $\begin{array}{l}0,79 \\
0,49 \\
0,71^{A} \\
\end{array}$ & $\begin{array}{l}0,86 \\
0,39 \\
0,68^{A} \\
\end{array}$ & $\begin{array}{l}0,67 \\
0,43 \\
0,44^{\mathrm{B}} \\
\end{array}$ & $\begin{array}{l}0,84 \\
0,58 \\
0,67^{A} \\
\end{array}$ & $\begin{array}{l}0,79^{b} \\
0,47^{d} \\
0,63^{c} \\
\end{array}$ \\
\hline Parcelas $^{3}$ & $0,72^{\alpha}$ & $0,67^{\alpha}$ & $0,54^{\beta}$ & $0,74^{\alpha}$ & \\
\hline $\begin{aligned} & 1 \text { Tempo } \\
& 2 \text { Média } \\
& 3 \text { Média } \\
& \text { abcd Médias } \\
& \alpha \beta \text { Médias } \\
& \text { AB Médias }\end{aligned}$ & $\begin{array}{l}\text { horas, ap } \\
\text { subparcela } \\
\text { parcelas ( } \\
\text { mesma co } \\
\text { mesma lin } \\
\text { mesma lin }\end{array}$ & $\begin{array}{l}\text { rnecimento } \\
\text { pos) } \\
\text { ntos) } \\
\text { guidas de } \\
\text { uidas de le } \\
\text { uidas de le }\end{array}$ & $\begin{array}{l}\text { stintas dife } \\
\text { intas difere } \\
\text { intas difere }\end{array}$ & $\begin{array}{l}\text { si a } 5 \% \\
\text { i a } 15 \% \\
\text { i a } 5 \% \text { d }\end{array}$ & $\begin{array}{l}\text { significância } \\
\text { significância } \\
\text { ignificância }\end{array}$ \\
\hline
\end{tabular}




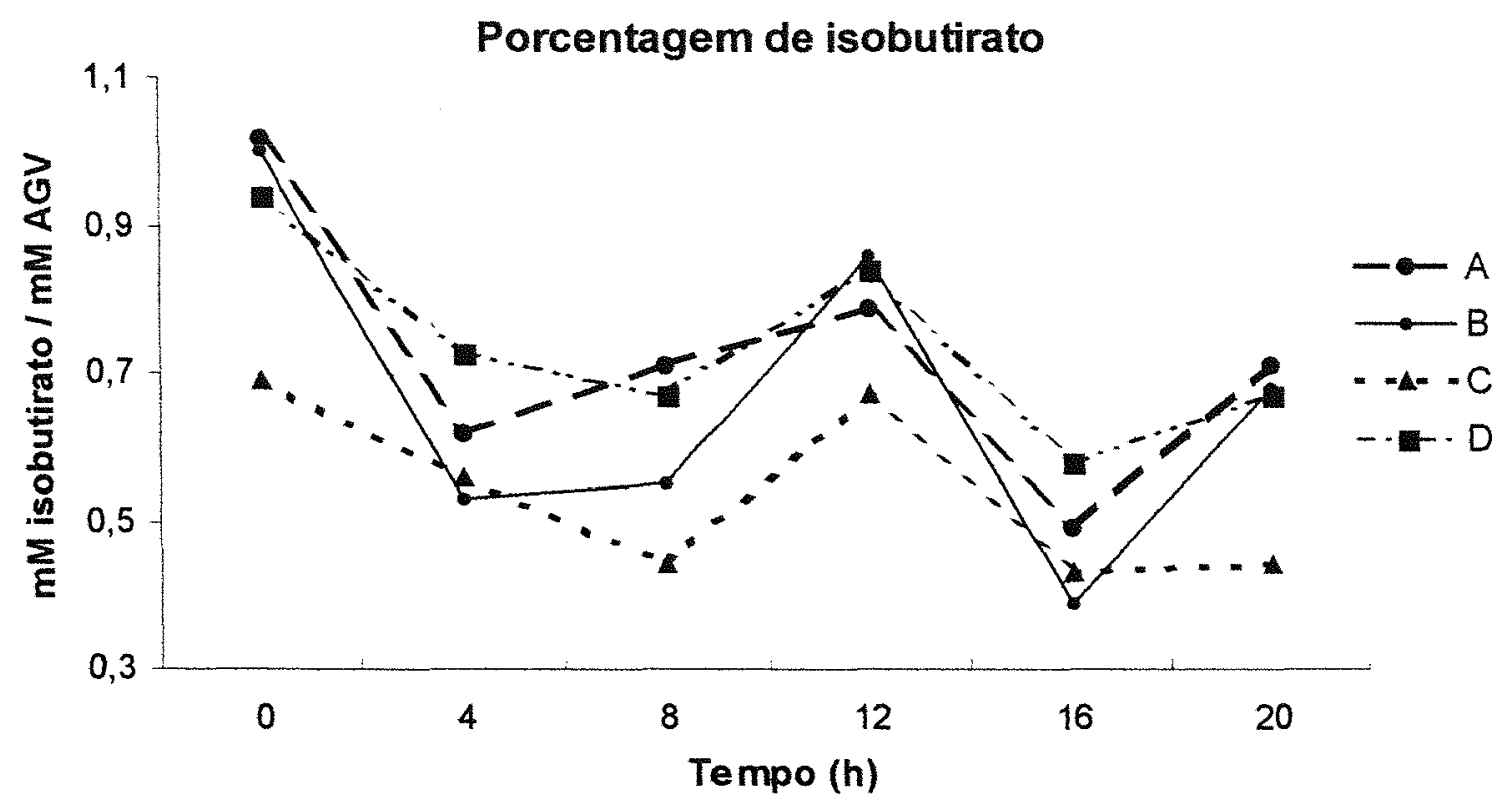

Figura 8. Efeito das dietas experimentais sobre a porcentagem molar de isobutirato no rúmen nos diferentes horários de amostragem em relação ao fornecimento matinal de alimento.

Houve interação $(\mathrm{P}<0,05)$ tratamento $x$ tempo para a porcentagem de isobutirato nos tempos zero, 4,8 e 20 horas após o fornecimento matinal do alimento. Houve efeito $(P<0,05)$ do tempo de coleta (subparcelas) sobre a porcentagem molar de isobutirato no fluido ruminal. No momento do fornecimento da dieta, observou-se valores médios de 0,91 e $0,79 \%$ nas coletas realizadas de manhã e de tarde, respectivamente, valores estes que coincidem com o picos de concentração deste AGV.

A dieta $C$ apresentou tendência $(P<0,15)$ para menor porcentagem de isobutirato que as demais.

Os dados referentes à análise da porcentagem molar de isovalerato estão apresentados na Tabela 14 e Figura 9. 
Tabela 14. Valores de quadrados mínimos da porcentagem de isovalerato em relação ao total de AGV no rúmen.

\begin{tabular}{|c|c|c|c|c|c|}
\hline \multirow{3}{*}{ Tempos ${ }^{1}$} & \multicolumn{4}{|c|}{ TRATAMENTOS } & \multirow{3}{*}{$\begin{array}{c}\text { Subparcelas }^{2} \\
P<0,05\end{array}$} \\
\hline & \multicolumn{2}{|c|}{$10,05 \% \mathrm{~PB}$} & \multicolumn{2}{|c|}{$13,70 \% \mathrm{~PB}$} & \\
\hline & $A$ & $B$ & $\mathrm{C}$ & $D$ & \\
\hline \multicolumn{6}{|l|}{ Dieta 6:00h } \\
\hline 0 & 2,39 & 2,68 & 1,88 & 2,21 & $2,29^{a}$ \\
\hline 4 & 1,73 & 1,96 & 1,68 & 2,08 & $1,87^{b}$ \\
\hline 8 & 1,93 & 2,19 & 1,60 & 1,99 & $1,93^{b}$ \\
\hline \multicolumn{6}{|l|}{ Dieta $18: 00 \mathrm{~h}$} \\
\hline 12 & 2,02 & 2,61 & 1,94 & 2,26 & $2,21^{a}$ \\
\hline 16 & 1,86 & 1,96 & 1,63 & 1,93 & $1,85^{\circ}$ \\
\hline 20 & 2,09 & 2,36 & 1,64 & 1,92 & $2,00^{b}$ \\
\hline Parcelas $^{3}$ & $2,01^{8}$ & $2,29^{A}$ & $1,73^{\mathrm{B}}$ & $2,07^{A B}$ & \\
\hline
\end{tabular}

1 Tempo, em horas, após o fornecimento matinal de alimento

Média das subparcelas (tempos)

3 Média das parcelas (tratamentos)

ab Médias na mesma coluna seguidas de letras distintas diferem entre si a $5 \%$ de significância

AB Médias na mesma linha seguidas de letras distintas diferem entre si a $5 \%$ de significância

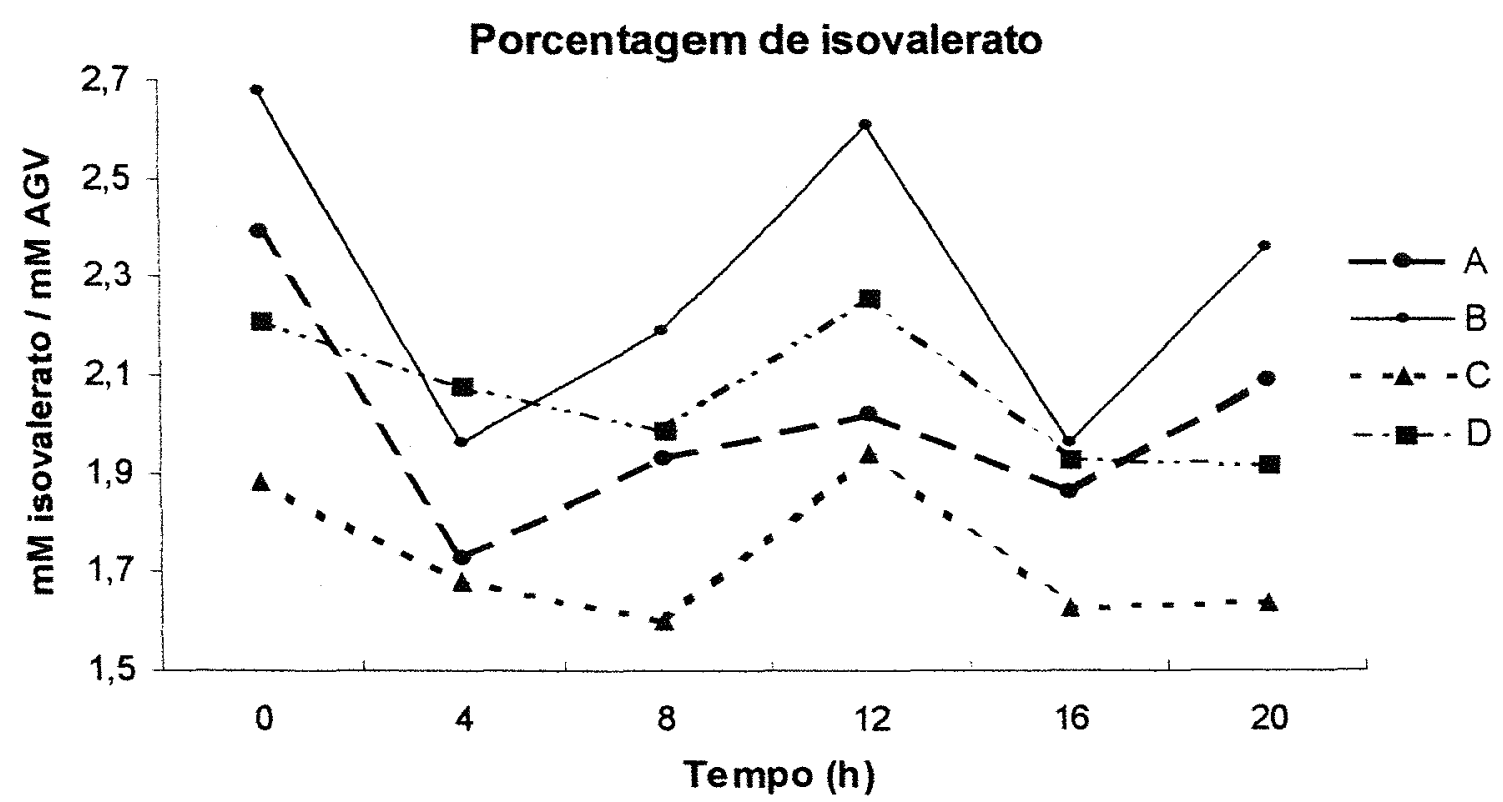

Figura 9. Efeito das dietas experimentais sobre a porcentagem molar de isovalerato no rúmen nos diferentes horários de amostragem em relação ao fornecimento matinal de alimento. 
Houve efeito $(P<0,05)$ do tempo de coleta (subparcelas) sobre a porcentagem molar de isovalerato no fluido ruminal. No momento do fornecimento da dieta, observou-se picos de concentração deste AGV, com queda significativa 4 e 8 horas após a alimentação da manhã e da tarde.

Não se observou diferença $(P>0,05)$ na interação tratamento $x$ tempo de porcentagens molares isovalerato no fluido ruminal.

A dieta $B$ ocasionou maiores concentrações molares de isovalerato $(\mathrm{P}<0,05)$ quando comparada com as dietas $\mathrm{A}$ e $\mathrm{C}$.

Os dados referentes à análise da porcentagem molar de valerato estão apresentados na Tabela 15 e Figura 10.

Tabela 15. Valores de quadrados mínimos da porcentagem de valerato em relação ao total de AGV no rúmen.

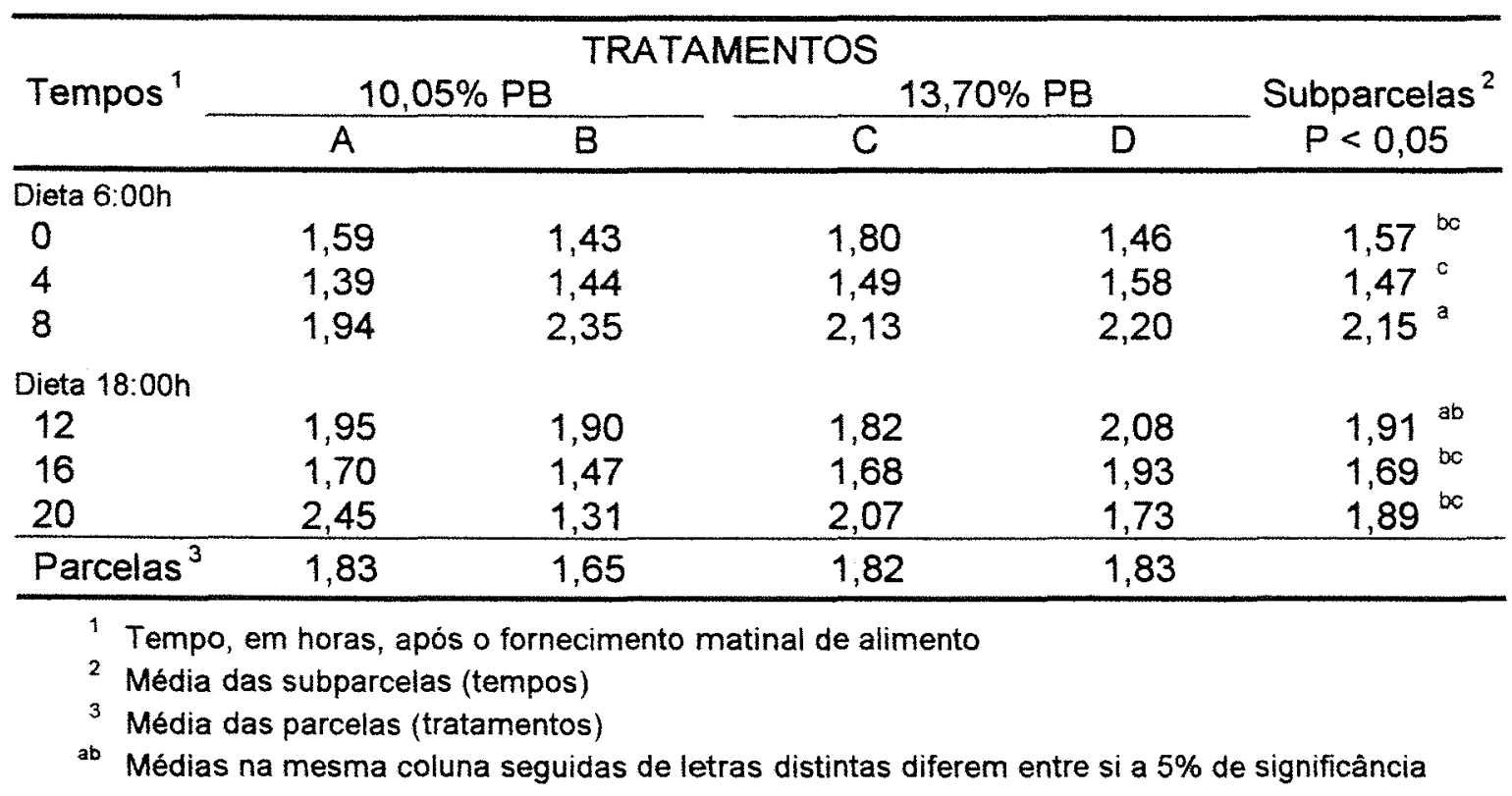




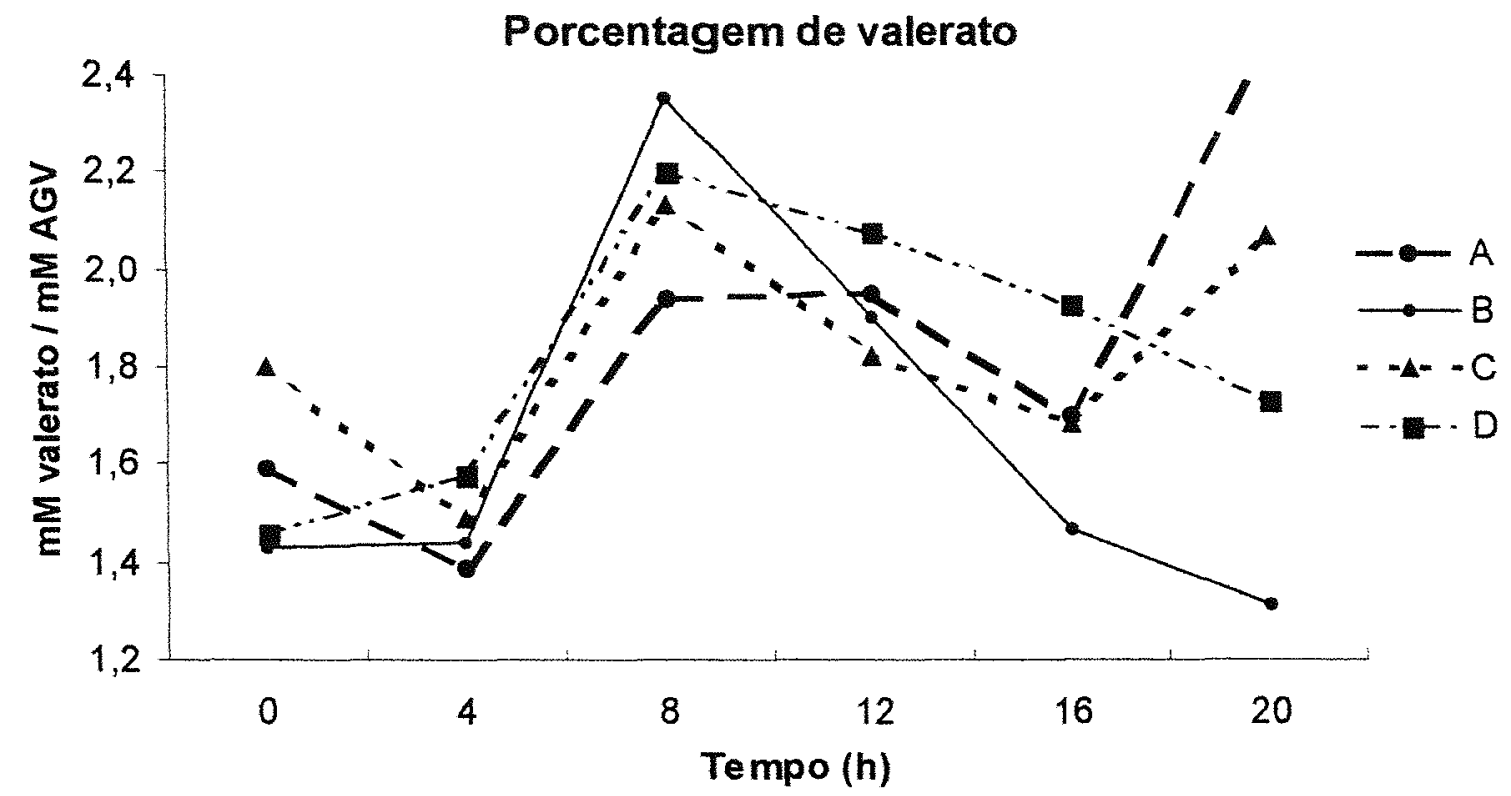

Figura 10. Efeito das dietas experimentais sobre a porcentagem molar de valerato no rúmen nos diferentes horários de amostragem em relação ao fornecimento matinal de alimento.

Houve efeito $(P<0,05)$ do tempo de coleta (subparcelas) sobre a porcentagem molar de valerato no fluido ruminal, com os valores mais baixos ocorrendo nos tempos 4 e 16 horas, ou seja, 4 horas após o fornecimento da dieta pela manhã e pela tarde. No momento do fornecimento da dieta, observou-se valores médios de 1,57 e 1,91\% nas coletas realizadas de manhã e de tarde, respectivamente.

Não houve efeito $(P>0,05)$ de tratamentos (parcelas) nem de interação tratamento $x$ tempo sobre a porcentagem molar de valerato no líquido ruminal. 


\subsection{Parâmetros sanguíneos}

\subsubsection{Glucose plasmática}

Os dados resultantes da análise de glucose plasmática estão exibidos na Tabela 16 e Figura 11.

Tabela 16. Valores médios da concentração de glucose plasmática (mg/dL)

\begin{tabular}{|c|c|c|c|c|c|}
\hline & & TR & VTOS & & \\
\hline Tempos $^{1}$ & & PB & & PB & Subparcelas $^{2}$ \\
\hline & $\mathrm{A}$ & $B$ & $C$ & $D$ & $P<0,05$ \\
\hline Dieta 6:00h & & & & & \\
\hline 0 & 57,23 & 56,50 & 54,18 & 52,20 & $55,03^{a}$ \\
\hline 2 & 53,45 & 50,65 & 51,65 & 51,73 & $51,87^{b}$ \\
\hline 4 & 52,65 & 55,70 & 54,63 & 51,48 & $53,61^{a b}$ \\
\hline 6 & 55,15 & 55,33 & 54,20 & 55,65 & $55,08^{a}$ \\
\hline Dieta 18:00h & & & & & \\
\hline 12 & 50,40 & 50,13 & 54,50 & 51,50 & $51,63^{b}$ \\
\hline 18 & 56,18 & 55,10 & 55,18 & 55,23 & $55,42^{a}$ \\
\hline Parcelas $^{3}$ & 54,18 & 53,90 & 54,05 & 52,96 & \\
\hline 1 Tempo, & , após & ecimento & aliment & & \\
\hline${ }^{2}$ Média d & arcelas & & & & \\
\hline 3 Média d & elas (tra & os) & & & \\
\hline ab Médias & ma colu & 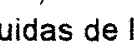 & & & cia \\
\hline
\end{tabular}

Houve efeito $(P<0,05)$ do tempo de coleta (parcelas) sobre a concentração plasmática de glucose, com os valores mais altos ocorrendo nos tempos 0,6 e 18 horas. No momento do fornecimento da dieta, observou-se valores médios de 55,03 e 51,63 mg/dL nas coletas realizadas de manhã e de tarde, respectivamente.

Não se observou diferença $(P>0,05)$ na concentração de glucose entre os valores médios diários de cada tratamento (parcelas) nem na interação tratamento $x$ tempo (Tabela 16 e Figura 11). 


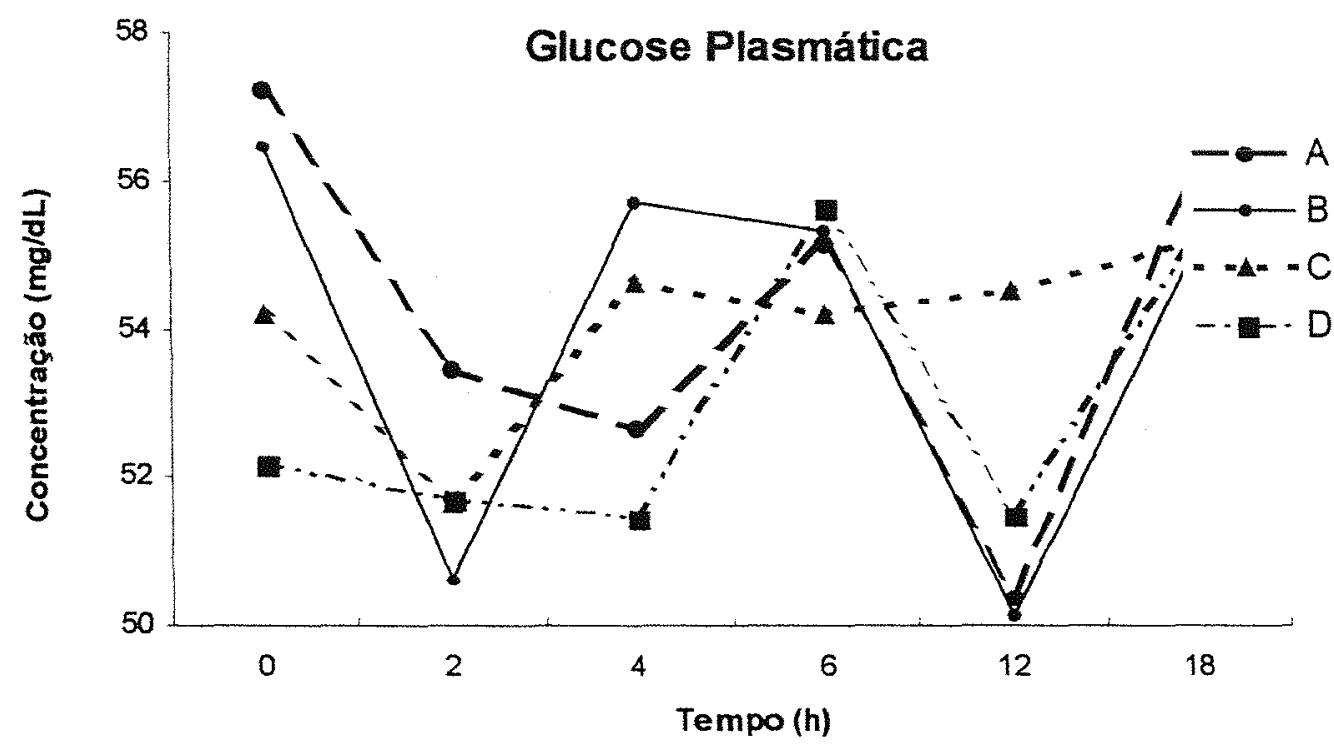

Figura 11. Efeito das dietas experimentais sobre a concentração de glucose plasmática nos diferentes horários de amostragem em relação ao fornecimento matinal de alimento.

\subsubsection{Uréia plasmática}

Os dados resultantes da análise de uréia plasmática estão apresentados na Tabela 17 e Figura 12.

Não houve efeito $(P>0,05)$ na concentração plasmática de glucose entre os tempos de coleta (subparcelas) nem na interação tratamento $x$ tempo. No momento do fornecimento da dieta, observou-se valores médios de 7,73 e $8,65 \mathrm{mg} / \mathrm{dL}$ nas coletas realizadas de manhã e de tarde, respectivamente.

Houve diferença $(P<0,05)$ entre os valores médios diários (parcelas) de cada tratamento. Os tratamentos com teores de $\mathrm{PB}$ maior ( $C$ e D) resultaram em maiores concentrações de uréia plasmática. A fonte de proteína utilizada, seja uréia ou farelo de soja não afetou a concentração de uréia plasmática. 
Tabela 17. Valores médios da concentração de uréia plasmática (mg N/dL)

\begin{tabular}{|c|c|c|c|c|c|}
\hline & & TRATA & ITOS & & \\
\hline Tempos $^{4}$ & 10,0 & & 13 & PB & Subparcelas ${ }^{2}$ \\
\hline & $A$ & $B$ & $C$ & $\mathrm{D}$ & $P<0,05$ \\
\hline Dieta 6:00h & & & & & \\
\hline 0 & 4,62 & 4,53 & 10,52 & 11,25 & 7,73 \\
\hline 2 & 5,15 & 6,13 & 12,13 & 11,73 & 8,79 \\
\hline 4 & 4,52 & 6,15 & 13,05 & 11,83 & 8,89 \\
\hline 6 & 4,76 & 6,10 & 13,45 & 10,71 & 8,75 \\
\hline Dieta 18:00h & & & & & \\
\hline 12 & 5,35 & 6,08 & 12,20 & 10,97 & 8,65 \\
\hline 18 & 5,33 & 5,97 & 12,67 & 12,09 & 9,02 \\
\hline Parcelas $^{3}$ & $4,95^{\mathrm{B}}$ & $5,83^{B}$ & $12,34^{A}$ & $11,43^{A}$ & \\
\hline 1 Tempo & após & ento $\mathrm{me}$ & alimento & & \\
\hline 2 Média d & arcelas (te & & & & \\
\hline 3 Média d & las (tratar & & & & \\
\hline AB Médias & na linha se & de letras & s diferem & a $5 \% \mathrm{de}$ & nificância \\
\hline
\end{tabular}

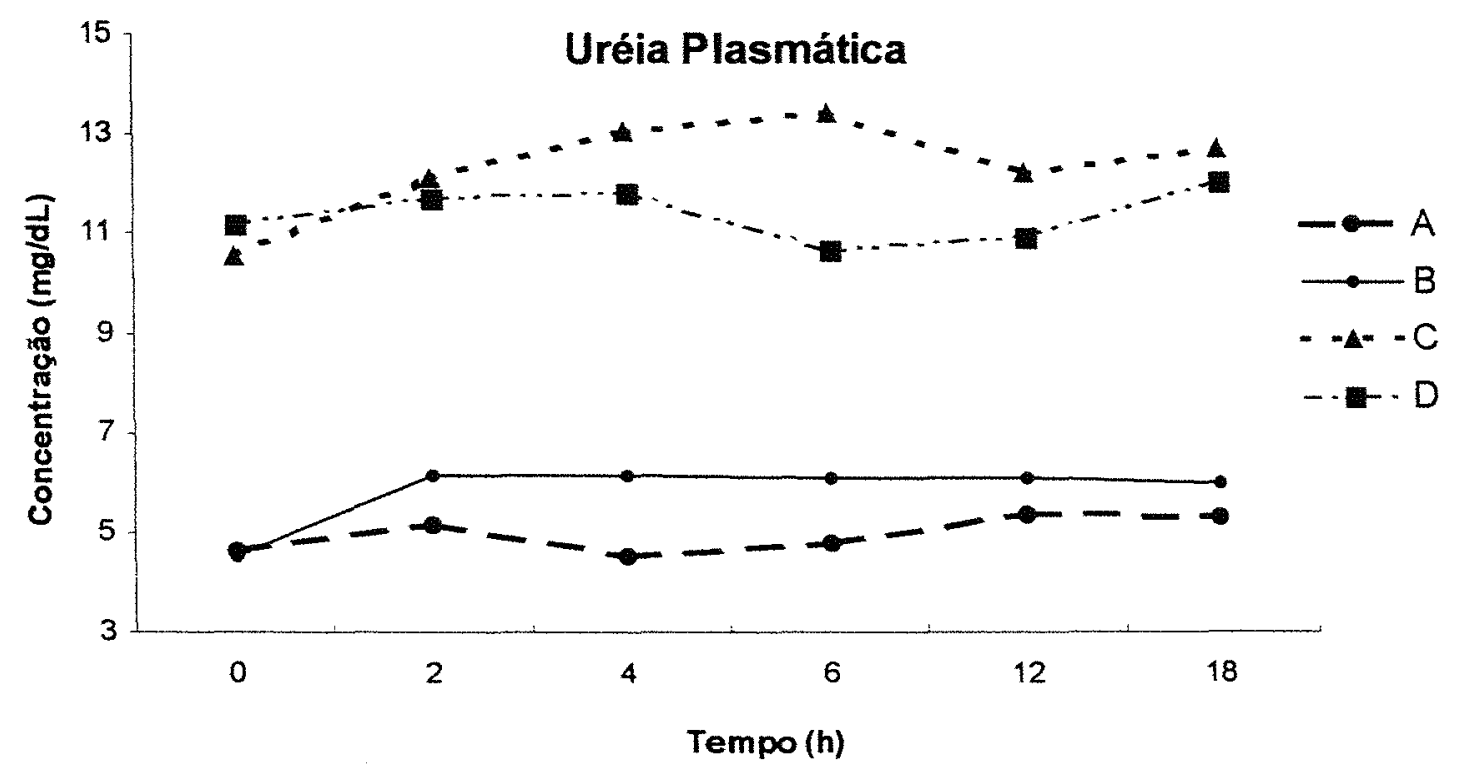

Figura 12. Efeito das dietas experimentais sobre a concentração de uréia plasmática nos diferentes horários de amostragem em relação ao fornecimento matinal de alimento. 


\subsection{Digestibilidade de nutrientes}

O cálculo da digestibilidade dos nutrientes no rúmen e trato total através do uso de óxido de cromo não foi possível, devido à inconsistência dos dados obtidos, ocorrendo o caso de se encontrar até mesmo digestibilidade negativa, similarmente ao que ocorreu com RIBEIRO (1999). Apesar de ainda se tentar utilizar a FDA indigestível livre de cinzas conforme descrito por NELSON et al. (1990), os dados continuaram a apresentar valores inconsistentes de digestibilidade. Como último recurso, procurou-se utilizar a lignina como marcador interno para obtenção de dados para o cálculo de digestibilidade, porém tal tentativa não permitiu sucesso no cálculo dos parâmetros de digestibilidade.

Portanto, o presente trabalho não foi capaz de obter dados que pudessem enriquecer a pesquisa conduzida.

\subsection{Fluxo de proteína microbiana}

O fluxo de proteína microbiana não foi possivel de ser determinado uma vez que os marcadores utilizados para se estimar a digestibilidade ruminal da matéria seca não apresentaram valores consistentes. 


\section{DISCUSSÃO DOS RESULTADOS}

Trabalhos conduzidos com vacas produzindo ao redor de 25 a $35 \mathrm{~kg}$ de leite/dia, mostraram respostas positivas em produção de leite ao aumento em PB da dieta de 10-12 para 13-16 (HUBER \& KUNG Jr., 1981). De modo geral o aumento em leite esteve sempre condicionado a um aumento no consumo de matéria seca nesses trabalhos.

No presente experimento, apesar da ausência de significância estatistica, houve numericamente um maior consumo de matéria seca e uma maior produção de leite quando o teor de proteína da dieta passou de 10,05 para $13,70 \%$. Um maior consumo de alimento com teores mais elevados de proteína na dieta, quando ocorre, se deve de modo geral a uma maior atividade fermentativa no rúmen, gerando maior produção de proteína microbiana e maior produção de AGV (HUBER \& KUNG Jr., 1981, EDWARDS et al., 1980; KUNG Jr. \& HUBER, 1983). Os valores numéricos mais baixos de $\mathrm{pH}$ ruminal $\mathrm{e}$ a significativa maior concentração molar de AGV nos tratamentos $C$ e $D$ são indicativos de uma maior atividade fermentativa no rúmen dos animais recebendo dietas com teores mais elevados em $\mathrm{PB}$. Isto permite inferir que os valores propostos por SATTER \& SLYTER (1974) de 2 a $5 \mathrm{mg}$ de $\mathrm{N}$-amoniacal por $100 \mathrm{~mL}$ de fluido ruminal são insuficientes para maximizar a atividade microbiana no rúmen, uma vez que os valores médios de $\mathrm{N}$-amoniacal observados para os tratamentos $A$ e $B$ foram respectivamente 3,67 e 4,3 contra 15,29 e $10,91 \mathrm{mg} / \mathrm{dL}$ para os tratamentos C e D.

A ausência de diferença entre as fontes protéicas testadas (uréia e farelo de soja) quanto ao consumo de alimento e produção de leite de vacas 
em final de lactação, produzindo entre 12 e $13 \mathrm{~kg} / \mathrm{dia}$ de leite, sugerem que para vacas com esse nivel de produção, o farelo de soja pode ser totalmente substituido pela uréia.

SANTOS et al. (1998) relataram que em 23 comparações onde uréia foi fornecida (0,4 a 1,8\% da MS da dieta) para vacas produzindo ao redor de $33 \mathrm{~kg}$ de leite por dia, em substituição parcial ou total às fontes suplementares de proteína verdadeira, a produção de leite não foi afetada negativamente em 19 comparações .

Segundo esses mesmo autores, vacas alimentadas com dietas ricas em amido degradável no rúmen seriam capazes de utilizar fontes protéicas ricas em PDR ou NNP com maior eficiência. Isso sugere que quando os animais recebem NNP substituindo parte da proteina verdadeira em dietas ricas em amido degradável no rúmen, como as contendo milho floculado, há chances dessas dietas levarem à produções similares quando comparadas com dietas contendo fontes exclusivas de proteína vegetal ou animal.

$A$ ausência de diferença $(P>0,05)$ entre os tratamentos para teor e produção de proteína no leite estão de acordo com os dados obtidos por JOHNSON et al. (1987), BATERMAN et al. (1994) e LINES \& WEISS (1996), que também não observaram efeitos sobre o teor de proteína no leite quando compararam o farelo de soja com uréia. No entanto, CASPER et al. (1990), estudando o efeito da inclusão de $1 \%$ de uréia no concentrado contendo farelo de soja e milho moido, observaram vantagens para o tratamento com uréia. Apesar de não terem determinado as frações nitrogenadas na proteína do leite, os autores especulam que o aumento no teor de proteína foi devido ao aumento na fração de NNP do leite.

O teor e produção de proteína do leite são determinados principalmente pela quantidade e pelo perfil de aminoácidos que chegam ao duodeno. Dos aminoácidos importantes para a sintese de proteina pela glândula mamária, a lisina e a metionina se destacam pelo fato de serem os 
aminoácidos mais limitantes para tal finalidade e a sua maximização é possivel de ser atingida caso a porcentagem destes dois aminoácidos no bolo alimentar do duodeno esteja em torno de 15 e $5 \%$ dos aminoácidos essenciais, respectivamente para a lisina e metionina (SCHWAB 1994), ou como mais recentemente preconizado por SLOAN et al. (1999), 6,82 e 2,19\% de lisina e metionina, respectivamente, na proteína metabolizável que chega ao duodeno. Os dados gerados neste estudo permitem concluir que a uréia quando incluída na dieta na dose de até $1,3 \%$ da MS, em combinação com o farelo de soja, foi tão eficiente quanto o farelo de soja exclusivo, em suprir aminoácidos para a glândula mamária de vacas produzindo entre 12 a $13 \mathrm{~kg}$ de leite por dia.

O maior teor de gordura no leite para o tratamento $B$ em relação aos demais não pode ser explicado pelos dados de $\mathrm{pH}$ ruminal, AGV totais, acetato, propionato ou mesmo relação acetato/propionato observados neste estudo.

LINES \& WEISS (1996) observaram que vacas recebendo NNP tenderam a ter maior produção de leite corrigido para gordura (LCG) a $4 \%$ do que aquelas alimentadas com fontes de proteína animal e/ou vegetal, devido à tendência dos animais que receberam NNP produzirem maior gordura no leite.

Similarmente, BRODERICK et al. (1993) também não observaram diferenças nas produções e teores de proteina e gordura do leite de vacas recebendo farelo de soja ou uréia.

De maneira geral, o teor de gordura no leite é influenciado pelo padrão de fermentação ruminal, de modo que, caso haja algum fator que possa ocasionar uma queda no $\mathrm{pH}$, ocorreria uma menor fermentação de substratos por parte das bactérias celulolíticas e, consequentemente, diminuindo a relação acetato/propionato no líquido ruminal.

No entanto, o mecanismo exato pelo qual a síntese de gordura no leite é comprometida ainda não está bem elucidado, mas algumas teorias têm sido propostas, sendo que a maioria delas envolvem as mudanças que ocorrem na 
fermentação ou metabolismo ruminal como sendo as principais razões que resultam na diminuição de precursores de gordura para a glândula mamária (VAN SOEST, 1963; SUTTON, 1989). Já os estudos mais recentes (WONSIL et al., 1994; GAYNOR et al., 1994) sugerem que a queda na síntese de gordura no leite é devido à presença de componentes provenientes da dieta ou da fermentação ruminal (como por exemplo os ácidos trans-octadecenóico), que inibem rotas metabólicas de biossíntese e dessaturase na glândula mamária (HAGEMEISTER, 1990).

Assim, as teorias referentes à diminuição de gordura no leite podem ser divididas em duas categorias distintas, a saber:

a) aquela que atribui a queda como consequência na diminuição do fornecimento de precursores de lipídios para a glândula mamária (VAN SOEST, 1963; SUTTON, 1989);

b) aquela que atribui a queda à inibição direta na síntese de gordura no leite: componentes provenientes da dieta ou produzidos na fermentação ruminal ou no metabolismo animal, como os ácidos trans-octadecenóico, ácido metilmalônico e ácidos graxos ciclopropenos (isto é, ácido estercúlico) (ASTRUP et al., 1975; PENNINGTON \& DAVIS, 1975). O ácido trans-11-octadecenóico (trans-11 $\mathrm{C}_{18: 1}$ ) é o principal intermediário do processo de biohidrogenação, promovido pelos microorganismos ruminais, para a formação do ácido esteárico a partir dos ácidos linoléico e linolênico (HARFOOT \& HAZELWOOD, 1988).

As respostas em produção e composição de leite sugerem que a proteína absorvida não foi limitante nas dietas que utilizaram uréia. 
Os dados resultantes da análise de concentração de $\mathrm{N}$-amoniacal no rúmen indicam que os valores médios observados foram mais influenciados pelo teor de proteína da dieta do que pela fonte protéica. Os dados sugerem que concentrações de $\mathrm{N}$-amoniacal no fluido ruminal da ordem de 2 a $5 \mathrm{mg} / \mathrm{dL}$ como proposto por SATTER \& SLYTER (1974) são atingidas facilmente com dietas contendo até $10 \%$ de PB, ou seja, teores raramente contidos em dietas para vacas leiteiras de alta produção ou até mesmo para animais em crescimento. A ocorrência de valores numéricos mais altos para consumo de MS e produção de leite, nas dietas contendo $13,70 \%$ de PB (C e D), e a maior concentração ruminal de AGV, estão de acordo com o proposto por HOOVER \& STOKES (1991), que concluiram que para se maximizar a síntese de proteína microbiana, as dietas para vacas leiteiras devem conter niveis de PDR ao redor de $13 \%$. Nesse caso, valores de $\mathrm{N}$-amoniacal entre 10 e $20 \mathrm{mg} / \mathrm{dL}$ são facilmente obtidos.

O NRC (1989) cita que o efluxo de $\mathrm{N}$ a partir do rúmen ocorre através da absorção e passagem de amônia e pode representar entre 16 e $80 \%$ do total de $\mathrm{N}$ ingerido (média de $40 \%$ ). O influxo para o rúmen ocorre através da difusão da uréia sanguínea e da secreção salivar e pode representar de 10 a $42 \%$ do total de $\mathrm{N}$ ingerido (média de $23 \%$ ).

WALLACE (1979) observou que há aumento no crescimento de bactérias ruminais quando se aumenta a concentração de amônia ruminal de 9,7 para $21,4 \mathrm{mg} / \mathrm{dl}$. O NRC (1989) cita que são necessários níveis de amônia ruminal em torno de 8 a $15 \mathrm{mg} / \mathrm{dL}$ ou concentrações de uréia sanguínea em torno de 8 a $10 \mathrm{mg} / \mathrm{dL}$ para se obter uma maximização da digestão da matéria orgânica no rúmen de vacas leiteiras.

WOHLT et al. (1978) observaram em seus estudos uma maior digestibilidade da MS quando a amônia ruminal esteve acima de $5 \mathrm{mg} / \mathrm{dL}$ do que quando esteve abaixo. 
A ausência de efeito sobre o $\mathrm{pH}$ ruminal das vacas que receberam dietas com teores mais elevados de proteina e especialmente das que receberam uréia pode ser explicado pela maior atividade fermentativa do rúmen, estimulado, uma vez que a deficiência em proteína degradável foi suprida, produzindo assim mais AGV. KUNG \& HUBER (1983) e WOHLT et al. (1978), também não observaram diferenças em tal parâmetro quando adicionaram uréia às dietas dos animais. Por outro lado, há trabalhos na literatura mostrando que a inclusão de uréia levou a aumentos no $\mathrm{pH}$ ruminal (POLAN et al., 1976), bem como em outros levou à diminuição nesta variável (CAMERON et al., 1991).

Provavelmente, o efeito da elevação do teor de proteína da dieta no pH ruminal pode ser alterado pelo teor de proteina inicial da dieta. Em situações onde o teor da dieta controle é baixo, ou seja, limita a atividade ruminal, adições extras de proteína levariam a um aumento da produção de AGV no rúmen, o que impediria elevação do $\mathrm{pH}$. Por outro lado, em dietas onde a atividade fermentativa já se encontra elevada, ou seja, o teor de proteina não é limitante, adições extras poderiam aumentar significativamente 0 teor de $\mathrm{N}$ amoniacal no rúmen, estimulando uma elevação do $\mathrm{pH}$.

As dietas com maior teor de PB levaram os animais a produzirem maiores concentrações médias diárias de AGV totais, sugerindo que tais dietas permitiram uma maior fermentação da matéria orgânica pelos microorganismos ruminais. ARIELI et al. (1996) concluíram que a concentração dos AGV no liquido ruminal sofre maior influência da degradabilidade ruminal da MO do que da PB.

No presente experimento, comparando-se tratamentos dentro de um mesmo teor de PB na dieta, observou-se que a substituição de farelo de soja por uréia resultou em concentrações molares de AGV no fluido ruminal similares $(P>0,05)$, corroborando com dados previamente publicados por outros pesquisadores (LINES \& WEISS, 1996; CAMERON et al. 1991). 
O perfil de $A G V$ produzidos no rúmen no presente estudo não foi afetado $(P>0,05)$ pelas fontes protéicas comparadas, concordando com pesquisas conduzidas por CAMERON et al. (1991) e CASPER et al. (1990), mas não com os dados de CASPER \& SCHINGOETHE (1986) e de BRODERICK (1986).

Entretanto, o perfil de AGV foi afetado $(P<0,05)$ pela concentração de PB da dieta. De modo geral, o aumento de 10,05 para $13,70 \%$ de PB na dieta, favoreceu uma maior porcentagem de propionato (não significativa, mas apenas numérica) e de butirato $(P<0,10)$ em detrimento de acetato. ARIELI et al. (1996) verificaram que vacas que receberam dietas com alto teor de MODR produziram $8 \%$ a menos acetato e $13 \%$ mais propionato do que animais recebendo baixo teor de MODR na dieta.

Em testes in vitro realizados por AIELLO et al. (1989), o butirato inibiu o uso do propionato para a gluconeogênese em hepatócitos. Tal inibição da gluconeogênese somada à diminuição no fornecimento de propionato para o fígado pode diminuir a quantidade de glucose sintetizada pelas células hepáticas quando se fornece dietas com características de padrão de fermentação ruminal que produzam pouco propionato e bastante butirato.

Entretanto, no presente estudo não se observou diferença $(P>0,05)$ na concentração de glucose entre os tratamentos. Esses dados estão de acordo com outros trabalhos encontrados na literatura, onde houve comparações entre farelo de soja e uréia (BRODERICK et al., 1993; GUIDI, 1999). Os resultados obtidos no presente experimento provavelmente estão em parte relacionados à não existência de diferença na concentração molar de propionato no líquido ruminal que, segundo HUNTINGTON (1997), é o principal substrato para a síntese de glucose (gluconeogênese) no fígado em vacas de leite. De acordo com LYCOS et al. (1997), o aparecimento líquido de glucose é dependente do balanço resultante da quantidade produzida e da utilizada pelos tecidos 
drenados pelo sistema porta (rúmen, intestinos, pâncreas, baço e gordura omental).

Os AGV de cadeia ramificada são produzidos após a digestão da proteína verdadeira no rúmen, a partir da deaminação e descarboxilação de $A A$ de cadeia ramificada (leucina, isoleucina e valina). Fontes de NNP não geram diretamente estes compostos. Este fato poderia explicar a tendência de valores mais baixos de isobutirato nos tratamentos $B$ e $C$. Estes dados, concordam com os publicados por GUIDI (1999) e BRODERICK (1986), que observaram em seus respectivos trabalhos que a suplementação com uréia levou a menores concentrações de isobutirato em relação ao total de AGV, devido ao menor conteúdo de proteína verdadeira nestes tipos de dieta.

Entretanto o mesmo não se observou para isovalerato e valerato, entrando em contradição com os dados apresentados por CAMERON et al. (1991), que não verificaram efeito da suplementação com uréia sobre a porcentagem molar de isovalerato no líquido ruminal de vacas em lactação.

Os tratamentos com teores de PB maiores ( $C$ e D) resultaram em maior concentração plasmática de uréia. Apesar dos dados do presente experimento indicar que os tratamentos que geraram maiores concentrações de amônia ruminal também terem refletido o efeito na concentração de uréia plasmática, BRODERICK \& CLAYTON (1997) observaram que a concentração de uréia no sangue possui alta correlação com a concentração de uréia no leite, mas não com a amônia ruminal. Segundo BRODERICK et al. (1993), concentrações sanguíneas de uréia inferiores a $4 \mathrm{mM}$ (ou inferiores a $11 \mathrm{mg}$ de $\mathrm{N} / \mathrm{dL}$ ) mostram que a quantidade de PDR pode estar sendo limitante na dieta. Isto parece ter ocorrido no presente trabalho, onde o consumo de MS e produção de leite foram numericamente inferiores e a produção de AGV significativamente inferior nas dietas contendo $10,05 \%$ de $\mathrm{PB}$, as quais apresentaram valores médios de uréia plasmática entre 4,95 a 5,83mg de N/dL. 
Por outro lado, o fornecimento insuficiente de energia na dieta de vacas de leite pode ocasionar excesso de amônia ruminal, aumento na absorção de amônia pelo epitélio ruminal, elevação nas concentrações de uréia plasmática e baixos teores de proteína no leite (VAN SOEST, 1994; HOOVER \& STOKES, 1991; NRC, 1989). 


\section{CONCLUSÕES}

Vacas leiteiras em final de lactação, produzindo entre 12 a $13 \mathrm{~kg}$ de leite por dia, podem receber uréia como principal suplemento protéico em substituição parcial ao farelo de soja, em dietas contendo ao redor de 13 a $14 \%$ de $\mathrm{PB}$, sem redução no seu desempenho.

Dietas para vacas em final de lactação, formuladas de acordo com o NRC(1989), contendo $10,05 \%$ de PB proveniente de fontes de alta degradabilidade ruminal como farelo de soja e uréia, ainda assim resultam em níveis de amônia limitantes à fermentação ruminal e crescimento microbiano. 


\section{REFERÊNCIAS BIBLIOGRÁFICAS}

A.O.A.C. Association of Official Analytical Chemists. Official Methods of Analysis. $12^{\text {nd }}$ Ed., Washington, D.C. 1990.

AIELLO, R.J.; ARMENTANO, L.E.; BERTICS, S.J.; MURPHU, A.T. Volatile fatty acid uptake and propionate metabolism in ruminant hepatocytes. Journal of Dairy Science. v. 72, p. 942. 1989.

ARIELI, A.; SHABI, Z.; BRUCKENTAL, I.; TAGARI, H.; AHARONI, Y.; ZAMWELL, S.; VOET, $H$. Effect of degradation of organic matter and crude protein on ruminal fermentation in dairy cows. Journal of Dairy Science. v. 79, p. 1774.1996.

ARMENTANO, L.E. Ruminant hepatic metabolism of volatile fatty acids, lactate and pyruvate. Journal of Nutrition, v. 122, p. 838. 1992.

ARMENTANO, L.E.; BERTICS, S.J.; RIESTERER, J. Lack of response to addition of degradable protein to a low protein diet fed to midlactation dairy cows. Journal of Dairy Science, v. 76, p.3755, 1993.

ASTRUP, H.N.; VIK-MO, L.; EKERN, A.; BAKKE, F. Feeding protected and unprotected oils to dairy cows. Journal of Dairy Science, v. 59, p. 426. 1975.

BATERMAN, T.G.; MARSHAL, R.T.; BELYEA, R.L.; KERLEY, M.S.; SPAIN, J.N. Comparison of rumen potected methionine and lysine on blood meal and fish meal as protein supplements for early lactation in Holstein cows. Journal of Dairy Science, v. 77:Supplement 1, p. 91. 1994.

BAUACHEMIN, K.A.; MCALLISTER, T.A.; DONG, Y.; FARR, B.I.; CHENG, K.J. Effects of mastication on digestion of whole cereal grains by cattle. Journal of Animal Science, v.72, p. 236. 1994.

BERGMAN, E.N. Energy contributions of volatile fatty acids from the gastrointestinal tract in various species. Physiological Reviews, v. 70, n. 2, p. 567. 1990. 
BRODERICK, G.A. Relative value of solvent and expeller soybean meal for lactating dairy cows. Journal of Dairy Science, v. 69, p. 2958. 1986.

BRODERICK, G.A.; CLAYTON, M.K. A statistical of animal and nutrition factors influencing concentrations of milk urea nitrogen. Journal of Dairy Science, v.80, p. 2964. 1997.

BRODERICK, G.A.; CRAIG, W.M.; RICKER, D.B. Urea versus true protein as supplement for lactating dairy cows fed grain plus mixtures of alfafa and corn silages. Journal of Dairy Science. v. 76, p. 2266. 1993.

CAMERON M.R.; KLUSMEYER, T.H.; LYNCH, G.L.; CLARK, J.H.; NELSON, D.R. Effects of urea and starch on rumen fermentation, nutrient passage to the duodenum, and performance of cows. Journal of Dairy Science, v. 74, p.1321. 1991.

CASPER, D.P.; SCHINGOETHE, D.J. Evaluation of urea and dried whey in diets of cows during early lactation. Journal of Dairy Science, v. 69, p. 1346. 1986.

CASPER, D.P.; SCHINGOETHE, D.J.; EISENBEISZ, W.A. Response of early lactation dairy cows fed diets varying in source of nonstructural carbohydrate and crude protein. Journal of Dairy Science, v. 73 , p. 1039. 1990.

CHANEY, A.L.; MARBACH, E P. Modified reagents for determination of urea and ammonia. Clinical Chemistry. V. 8, p. 130. 1962.

COTTA, M.A.; RUSSEL, J.B. The effect of peptides and amino acids on deficiency of rumen bacterial protein synthesis in continuous culture. Journal of Dairy Science, v. 65, p. 226. 1982.

DePETERS, E.J.; CANT, J.P. Nutritional factors influencing the nitrogen composition of bovine milk: a review. Journal of Dairy Science. v. 75, p. 2043. 1992.

EDWARDS, J.S.; BARTLEY, E.E.; DAYTON, A.D. Effects of dietary protein concentrations on lactating cows. Journal of Dairy Science, v. 63, p. 243. 1980.

ERFLE, J.D.; MAHADEVAN, R.M.; TEATHER, R.M.; SAUER, F.D. The performance of lactating cows fed urea treated corn silage in combination with soybean or fish meal containing concentrates. Canadian Journal of Animal Science, v. 63, p.191. 1983. 
FAHEY, G.C.; BERGER, L.L. Carbohydrate nutrition of ruminants. In: $\mathrm{CHURCH}$, D.C. The ruminant animal: Digestive physiology and nutrition Englewood Cliffs: Simon \& Schuster, p. 269. 1988.

FENTON, T.W.; FENTON. Na improved procedure for determination of chromic oxide in feed and feces. Canadian Journal Animal Science, v.59, p. 631. 1979.

FERGUSON, J.D.; CHALUPA, W. Impact of protein nutrition on reproduction in dairy cows. Journal of Dairy Science. v. 72, p. 746. 1989.

FRASER, D.L.; ØRSKOV, F.G.; WHITELAW, F.G.; FRANKLIN, M.F. Limiting amino acids in dairy cows given casein as the sole source of protein. Livestock Production Science, v. 28, p. 235. 1991.

GAYNOR, P.J.; ERDMAN, R.A.; TETER, B.B.; SAMPUGNA, J.; CAPUCO, A.V.; WALDO, D.R.; HAMOSH, M. Milk fat yield and composition during abomasal infusion of cis or trans octadecenoates in Holstein cows. Journal of Dairy Science, v.77, p. 157. 1994.

GRAY, G.M. Starch digestion and absorption in nonruminants. Journal of Nutrition, v. 122, p. 172. 1992.

GUIDI, M.T. Efeito de teores e fontes de proteína sobre o desempenho de vacas de leite e digestibilidade dos nutrientes. Dissertação (mestrado) Escola Superior de Agricultura Luiz de Queiroz, Universidade de São Paulo, Piracicaba, 92 p. 1999.

HAGEMEISTER, $\mathrm{H}$. Utilization of fat in dairy cattle feeding with attention being placed on trans fatty acids formed in the rumen. Kiel. Milchwirtsch. Forschungsber, v. 42, p. 271. 1990.

HARFOOT, C.G.; HAZELWOOD, G.P. Lipid metabolism in the rumen. Pages 285-322 In: The Rumen Microbial Ecosystem. P.N. Hobson, ed. Elsevier Sci. Publ. Ltd., London, England. 1988.

HARMON, D.L. Review: Impact of nutrition on pancreatic exocrine and endocrine secretion in ruminants. Journal of Animal Science, v. 70, p.1290. 1992.

HERRERA-SALDANA, R.; HUBER, J.T. Influence of varying protein and starch degradabilities on performance of lactating cows. Journal of Dairy Science, v.72, p.1477. 1989. 
HERRERA-SALDANA, R; GOMES-ALARCON, R.; TORABI, M.; HUBER, J.T.. Influence of synchronizing protein and starch degradation in the rumen on nutrient utilization and microbial protein synthesis. Journal of Dairy Science, v.73, p.142. 1990.

HOOVER, C.W.; STOKES, S.R. Balacing carbohydrates and proteins for optimum rumen microbial yield. Journal of Dairy Science. v. 74, p. 3630. 1991

HUBER, J.T.; KUNG Jr., L. Protein and non-protein nitrogen utilization by dairy cattle. Journal of Dairy Science, v. 64, p. 1176. 1981.

HUNGATE, R.E. The Rumen and Its Microbes. Academic Press, New York, 1966.

HUNTINGTON, G.B. Ruminant starch utilization progress has been extensive. Feedstuffs, June 6, p. 35. 1994.

HUNTINGTON, G.B. Starch utilization by ruminants: from basics to the bunk . Journal of Animal Science. v. 75, p. 852. 1997.

JOHNSON, C.O.L.E.; HUBER, J.T.; KING, K.J. Storage and utilization of brewers wet grains in diets for lactating dairy cows. Journal of Dairy Science, v. 70, p. 98.1987.

KOTARSKI, K.K.; WANISHA, R.D.; THURN, K.K. Starch hidrolysis by the ruminal microflora. Journal of Nutrition, v. 122, p. 178. 1992.

KUNG Jr., L.; HUBER, J.T. Performance of high producing cows in early lactation fed protein of varying amounts, sources and degradability. Journal of Dairy Science, v. 66, p.227. 1983.

KUNG Jr., L.; HUBER, J.T. Performance of high producing cows in early lactation fed protein of varying amounts, sources and degradability. Journal of Dairy Science, v. 66, p. 227. 1983.

LEHNINGER, A.L. Princípios da Bioquímica. Sarvier, São Paulo, 725 p. 1988.

LINES, L.W.; WEISS, W.P. Use of nitrogen from ammoniated alfafa hay, urea, soybean meal and animal protein meal by lactating cows. Journal of Dairy Science, v. 79, p. 1992-99. 1996.

LYCOS, T.; VARGA, G.A.; CASPER, D. Varying degradation rates of total nonstructural carbohydrates: Effects on ruminal fermentation, blood 
metabolities and milk production and composition in high producing Holstein cows. Journal of Dairy Science, v. 80, p. 3341. 1997.

MCALLISTER, T.A.; RODE, L.M.; MAJOR, D.J. CHUNG, K.J. Microbial attachment and feed digestion in the rumen. Journal of Animal Science, v.72, p. 3004.1994.

MOORE, J.A.; POORE, M.H.; ECK, T.P.; SWINGLE, R.S.; HUBER, J.T; ARANA M.J. Sorghum grain processing and buffer additions for early lactation dairy cows. Journal of Dairy Science, v. 75, p. 3465. 1992.

NATIONAL RESEARCH COUNCIL. Nutrient Requeriments of Dairy Cattle, 6 ed., Washington, National Academy of Science. 1989.

NATIONAL RESEARCH COUNCIL. Ruminant Nitrogen Usage. Washington, National Academy of Science. 1985.

NELSON, M.L.; MOTJOPE, L.; FINLEY, J.W.; PARISH, S.M. Ash-free indigestible acid detergent fiber as na internal marker to estimate digetibility with grazing ruminants. Journal of Range Management, v.43, p. 224.1990.

NOCEK, J. E.; RUSSELL, J.B. Protein and energy as an integrated system: Relationship of ruminal protein and carbohydrate availability to microbial synthesis and milk production. Journal of Dairy Science, v.71, p.2070. 1988.

NOCEK, J. E.; TAMMINGA, S. Site of digestion of starch in the gastrointestinal tract of dairy cows and its effect on milk and composition. Journal of Dairy Science, v.74, p.3598. 1991.

NORLAN, J. V. Quantitative models of nitrogen metabolism in sheep. In: Digestion and metabolism in the ruminant. I.W. MacDonald and A. C. I. Waner eds. Univ. New England Publishing Unit. Armidale, Australia, p.416. 1975.

O'MARA, F.P.; MURPHY, J.J.; RATH, M. Effect of amount of dietary supplement and source of protein on milk production, ruminal fermentation, and nutrient flows in dairy cows. Journal of Dairy Science, v. 81, p. 2430. 1998.

OWENS, F.N.; GOETSCH, A.L. Digesta passage and microbial protein synthesis. In: MILLIGAN, L.P.; GROVUM, W.L.; DOBSON, A. (Ed.) 
Control od digestion and metabolism in ruminants. New Jersey: Prentice Hall, p. 196. 1986.

OWENS, F.N.; ZINN, R. Protein metabolism of ruminant animals. In: $\mathrm{CHURCH}$, D.C. The ruminant animal: Digestive physiology and nutrition Englewood Cliffs: Simon \& Schuster, cap.2, p. 227. 1988.

PALMQUIST, D.; CONRAD, $\mathrm{H}$. Origin of plasma fatty acids in lactating cows fed high fat diets. Journal of Dairy Science, v. 54, p. 1025. 1971.

PENNINGTON, J.A.; DAVIS, C.L. Effects of intraruminal and intraabomasal additions of cod liver oil on milk fat production in the cow. Journal of Dairy Science, v. 58, p. 49.1975.

POLAN, C.E.; MILLER, C.N.; MCGILLIARD, M.L. variable dietary protein and urea for intake and production in Holstein cows. Journal of Dairy Science, v. 59, p. 1910. 1976.

POORE, M, H.; MOORE, J, A.; SWINGLE, R, S.; ECK, T, P.; BROW, W, H. Wheat straw or alfafa hay in diets with $30 \%$ neutral detergent fiber for lactating Holstein cows. Journal of Dairy Science, v. 74, p. 3152. 1991.

REYNOLDS, C.K.; HUNTINGTON, G.B. Net portal absorption of volatile fatty acids and $L(+)$ lactate by Holstein cows. Journal of Dairy Science, v.71, p. 124. 1988.

RIBEIRO, C.V.D.M. Efeito da substituição do grão de milho pelo de milheto (Pennisetum americanum) na dieta de vacas em lactação. Dissertação (mestrado) - Escola Superior de Agricultura Luiz de Queiroz, Universidade de São Paulo, Piracicaba, 67 p. 1999.

ROBINSON, P.H. Dynamic aspects of feeding management for dairy cows. Journal of Dairy Science, v. 72, p. 1197. 1989.

ROONEY, L. W.; PFLUGFELDER, R.L. Factors affecting starch digestibility with special emphasis on sorghum and corn. Journal of Animal Science, $v$. 63, p. 1607.1986.

RULQUIN, H.; VERITÉ, R. Amino acid nutrition of dairy cows. Productive effects and animal requirements. In: Garnsworthy, P.C. \& Cole, D.J.A. Recent Advances in Animal Nutrition, Nottingham Univ. press, p. 55. 1993. 
RUSSEL, J.B.; HESPELL, R.B. Microbial rumen fermentation. Journal of Dairy Science. v. 64, p. 1153. 1981.

RUSSEL, J.B.; SNIFFEN, C.J. Effect of carbon-4 and carbon-5 volatile fatty acids on growth of mixed rumen bacteria in vitro. Journal of Dairy Science. v. 67 , p. 987.1984.

RUSSEL, J.B.; SNIFFEN, C.J.; VAN SOEST, P.J. Effect of carbohydrate limitation on degradation and utilization of casein by mixed rumen bacteria. Journal of Dairy Science. v. 66, p. 763. 1983.

SANTOS, F.A.P.; SANTOS, J.E.P.; THEURER, C.B.; HUBER, J.T. Effects of rumen-undegradable protein on dairy cow performance: a 12-year literature review. Journal of Dairy Science, v. 81, p. 3182. 1998.

SANTOS, F.P.; HUBER, J.P. Quality of bypass proteins fed to high-producing cows is important. Feedstuffs, v. 68, n.34, p.12. 1996.

SAS Users Guide: Statistics, Version 5 Edition. 1991. SAS Inst., Inc., Cary, NC.

SATTER, L.D.; SLYTER, L.L. Effect of ammonia concentration on rumen microbial protein production in vitro. British Journal of Nutrition, v. 32, ก. 2, p. 199. 1974.

SCHAEFER, D.M.; DAVIS, C.L.; BRYANT, M.P. Ammonia saturation constants for predominant species of rumen bacteria. Journal of Dairy Science, $v$. 63, p. 1248.1980.

SCHWAB, C.G. Amino acid nutrition of the dairy cow: current status. In: Proceedings of Cornell Nutrition Conference. Cornell University, Ithaca, NY. 1996.

SCHWAB, C.G. Optimizing amino acid nutrition for optimum yields of milk and milk protein. In: Proceedings Southwest Nutrition and Management Conference. University of Arizona, Tucson, p. 114. 1994.

SCHWAB, C.G.; BOZAK, C.K.; WHITEHOUSE, N.L.; MESBAH, M.M.A. Amino acid limitation and flow to duodenum at four stages of lactation. 1. Sequence of lysine and methionine limitation. Journal of Dairy Science, v. 75, p. 3486.1992.

SCHWAB, C.G.; SATTER, L.D.; CLAY, A.B. Response of lactating cows to abomasal infusion of amino acids. Joumal of Dairy Science, v. 59, p. 1254. 1976. 
SLOAN, B.K.; GARTHWAITE, B.D.; SCHWAB, G.S. Fine-tuning sub-model may optimize production. Feedstuffs. V. 71, August 9, p. 11. 1999.

SNIFFEN, C.J.; ROBINSON, P.H. Microbial growth and flow as influenced by dietary manipulations. Journal of Dairy Science, v. 70, p. 425. 1987.

SUTTON, J.D. Altering milk composition by feeding. Journal of Dairy Science, v. 72, p. 2801.1989.

SWENSON, M.J.; REECE, W.O. Dukes Fisiologia dos Animais Domésticos. Rio de janeiro: Guanabara Koogan, 856 p. 1996.

TAMMINGA, S. Nutritional management of dairy cows as a contribution to pollution control. Journal of Dairy Science, v. 75, p. 345. 1992.

THEURER, C.B. Grain processing effects on starch utilization by ruminants. Journal of Animal Science, v. 63, p. 1649. 1986.

THEURER, C.B. Steam-flked grain for high producing dairy cows. In: Proceedings of Southwest Nutrition and Management Conference. University of Arizona, Tucson. 1992.

THEURER, C.B.; HUBER, J.T.; CHEN, K.H.; SWINGLE, R.S. Update on grain processing research in lactating cows. In: Proceedings of Southwest Nutrition and Management Conference. University of Arizona, Tucson. 1993.

THEURER, C.B.; HUBER, J.T.; SANTOS, F.A.P. Feeding and managing for maximal milk protein. In: Proceedings of Southwest Nutrition and Management Conference. University of Arizona, Tucson. p.59. 1995.

VAN SOEST, P.J. Nutrition ecology of the ruminants. Ithaca, New York. Cornell University Press, 476 p. 1994.

VAN SOEST, P.J. Ruminant fat metabolism with particular reference to factors affecting low milk fat and feed efficiency. A review. Journal of Dairy Science, v. 46, p. 204. 1963.

VAN SOEST, P.J.; ROBERTSON, J.B.; LEWIS, B.A. Methods for dietary fiber, neutral detergent fiber, and nonstarch polysaccharides in relation to animal nutrition. Journal of Dairy Science, v.74, p. 3583. 1991.

WALLACE, R.J. Effect of ammonia concentration on the composition, hydrolytic activity and nitrogen metabolism of the microbial flora of the rumen. Journal of Applied Bacteriology, v. 47, p. 443. 1979. 
WOHLT, J.E.; CLARK, J.H. Nutritional value of urea versus preformed protein for ruminants. I. Lactation of dairy cows fed corn based diets containing supplemental nitrogen from urea and/or soybean meal. Journal of Dairy Science, v. 61, p. 902. 1978.

WOHLT, J.E.; CLARK, J.H.; BLAISDELL, F.S. Nutritional value of urea versus preformed protein for ruminants. II. Nitrogen utilization by dairy cows fed corn based diets containing supplemental nitrogen from urea and/or soybean meal. Journal of Dairy Science, v. 61, p. 916. 1978.

WONSIL, B.J.; HERBEIN, J.H.; WATKINS, B.A. Dietary and ruminally derived trans-18:1 fatty acids alter bovine milk lipids. Journal of Nutrition. 124, p. 556. 1994.

YOKOYAMA, M.T.; JOHNSON, K.A. Microbiology of the rumen and intestine. In: $\mathrm{CHURCH}$, D.C. The ruminant animal: Digestive physiology and nutrition Englewood Cliffs: Simon \& Schuster, p. 125. 1988.

ZINN, R.A.; OWENS, F.N. A rapid procedure for purine measurement and its use for estimating net ruminal protein synthesis. Canadian Journal of Animal Science, v. 66, p. 157. 1986. 